\title{
Tajik Persian: Readings in \\ History, Culture and Society
}

\author{
Razi Ahmad
}

University of Kansas Libraries 


\title{
Tajik Persian: Readings in
}

\section{History, Culture and Society}

\author{
Razi Ahmad
}




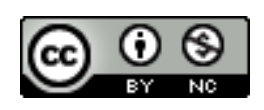

This work is licensed under a Creative Commons Attribution-Noncommercial 4.0 International License (CC-BY-NC 4.0).

\section{You are free to:}

- Share - copy and redistribute the material in any medium or format

- Adapt - remix, transform, and build upon the material

\section{Under the following terms:}

- Attribution - You must give appropriate credit, provide a link to the license, and indicate if changes were made. You may do so in any reasonable manner, but not in any way that suggests the licensor endorses you or your use.

- NonCommercial - You may not use the material for commercial purposes.

No additional restrictions - You may not apply legal terms or technological measures that legally restrict others from doing anything the license permits.

The licensor cannot revoke these freedoms as long as you follow the license terms.

3rd party content belongs to the original sources as indicated and is not governed by the CC license. Their terms of use may vary. 


\section{Acknowledgement}

Tajik Persian: Readings in History, Culture and Society grew out of the materials developed for the purpose of teaching Language Across the Curriculum (LAC) courses in Tajik offered through the Center for Russian, East European \& Eurasian Studies (CREES) at the University of Kansas. I extend my thanks to the former director of the center Professor Edith Clowes for accepting my LAC proposal and encouraging me in developing such courses. I would also like to thank Professor Marc Greenberg (Director, KU School of Languages, Literatures, and Cultures) for his encouragement in preparing the textbook.

I must express my gratitude to Dildora Toshmatova for her invaluable contributions in collecting and developing the materials for this book. I would also like to thank Shamsullo Mirzoev for sharing his insights and editing and proofreading the draft as a native speaker. I am grateful to Marianne Reed (Digital Initiatives Coordinator, KU Libraries) and Josh Bolick (Scholarly Communications Librarian, KU Libraries) for their advice and Pam LeRow (CLAS/Digital Media Service) for technical assistance. Finally, I thank my wife Tasnim Fatma for her patience and never ending support.

Of course, any shortcomings are mine. 
CHAPTER 1: SAMANID STATE STRUCTURE

Сохти давлатй ва ташкили дастгохи идораи Сомониён

CHAPTER 2: STATUES OF BUDDHA

мучассамахои буддой

CHAPTER 3: ABŪ ABDULLĀH RŪDAKI

Абӯабдулло Рўдакй.

CHAPTER 4: RUSSIAN OCCUPATION OF CENTRAL ASIA

Забти Осиёи Миёна аз тарафи Русия.

CHAPTER 5: MIRZO TURSUNZODA

Мирзо Турсунзода

CHAPTER 6: TAJIK CIVIL WAR

Чанги Шахрвандии Точикистон

CHAPTER 7: MILITARY COLLEGE

Донишкадаи харбй

CHAPTER 8: CHAPTER 9: RELIGIOUS EDUCATION IN TODAY'S TAJIKISTAN

Маорифи динй дар Точикистони имрӯза .....................................36

CHAPTER 9: ENTREPRENEURSHIP: THE DRIVING FORCE OF MARKET ECONOMY

Сохибкорй фишанги иқтисоди бозорист

CHAPTER 10: BLOOD PRESSURE AND HEALTH

Фишори Хун Ва Тандурустй .46

CHAPTER 11: CAN AN OLD MAID BE LUCKY?

Пирдухтар хушбахт мешавад?

CHAPTER 12: NAVRUZ FESTIVAL

Давоми Ниёгон 56

KEY TO EXERCISES 61

TAJIK-ENGLISH GLOSSARY .65 


\section{Preface}

Tajik Persian belongs to the Indo-European language family, uses - unlike its other two variants Iranian and Dari Persian written in the Arabic-based script - modified version of the Cyrillic alphabet, and serves as the official language of Tajikistan. The primary purpose of Tajik Persian: Readings in History, Culture and Society is to help students develop reading proficiency in Tajik at advanced level.

The book can be adopted by instructors as a supplementary or the main textbook for advanced-level courses. Since it is not a basic language textbook or workbook, it expects students to be familiar with the intermediate-level vocabulary and modern Tajik grammar, provides explanation of only a select number of difficult grammatical points, and, if necessary, directs to the grammar books available in the market. It is recommended to use John R. Perry, A Tajik Persian Reference Grammar (Leiden, Boston: Brill Academic Pub-lishers: 2005), hitherto the most comprehensive grammar for the language in English, as a companion reference book. The reading texts are followed by a list of difficult words and exercises for comprehension check. The answer keys for all the exercises are provided at the end of the book.

The book aims at improving general reading comprehension and provides students glimpses into the history, culture and society of Tajikistan in chronological order, but the majority of readings have been carefully selected and arranged to keep the focus on cultural aspects of the countryan aspect that constitutes a core component in the second language acquisition. It can be used to create opportunities for students to engage in debate and discussion on various topics in their historical and sociocultural contexts. For example, the first chapter is on the Samanids, one of the earliest non-Arab Muslim rulers in the region, followed by a reading on statues of Buddha, indicative of a practice strictly prohibited in Islam. The two chapters together provide an interesting historical and sociocultural context to discuss Tajik arts and aesthetics and their production. The book, however, does not aspire to be a substitute for scholarly books on history and culture. One may like to consult original sources from which readings have been extracted or follow the suggested books and articles, given in footnotes, for a better understanding of the topics.

All the readings in Tajik Persian: Readings in History, Culture and Society are authentic and written for native speakers. It is hoped that it will help students prepare for carrying out research using primary sources in the target language. 


\section{CHAPTER 1: THE SAMANID STATE STRUCTURE}

\section{Сохти давлатй ва ташкили дастгохи идораи Сомониён}

Асосгузори давлати Сомониён Исмоили Сомонй ба хубй медонист, ки таъмин кардани истиқлолияти Мовароуннахр ва аз хилофати Араб озодона нашъунамо ёфтани вай фақат хамон вақт мумкин мешавад, ки дар ин мамлакат як хукумати марказият пайдо кардае ба вучуд ояд ${ }^{1}$. Вай дар рохи ин мақсад як қатор иқдомот ба амал овард.

Яке аз ин навъ икдомот чорй намудани усули мутаносиби идораи давлат буд. Дар ахди Сосониён дастгохи давлатй ба даргох (дарбори подшохй) ва девонхо (идорахои марказии харбй-гражданй) тақсим мегардид. Дар шароити хаёти феодалй ба ин тақсимот он қадар хам риоя карда намешуд²: одамони бонуфузи дарбор аксар вақт ба корхое мудохила мекарданд, ки вазифаи ин ва ё он девон ба шумор мерафт. Чи навъе ки Наршахй қайд мекунад, дар замони салтанати Насри II Сомонй (914943) дар атрофи Регистони Бухоро дах бинои олй барои девонхо сохта буданд. ${ }^{3}$ Девонхо аз 10 идораи марказй иборат буда, аз рӯи вазифахои худ ба сохахои зерин тақсим мешуданд:

Девони вазир асоситарин идораи марказй хисоб мешуд ва дар тамоми муассисахои маъмурй, сиёсй ва иқтисодии давлат ${ }^{4}$ назорат менамуд. Ба вай сардорони хамаи девонхои дигар итоат мекарданд. Ба мансаби сардори ин девон, яъне ба вазифаи вазирй ё хочиби бузург, одатан яке аз намояндагони се хонавода: Чайхонй, Балъамй ва Утбй таъин мешуданд. Тамоми куввахои харбии Сомониён дар ихтиёри хочиби бузург буд.

Девони муставфй хамаи корхои молиявй, яъне харчу дахли мамлакатро пеш мебурд.

Девони амид-ул-мулк ба хамаи қоғазхои мухими давлатй маъмур буда, инчунин муносибатхои дипломатиро бо дигар давлатхо идора мекард.

Девони сохуиб-уш-щурот гвардияи Сомониёнро дар ихтиёри худ нигох медошт, ба озуқа, мохона ва нигохбини лашкар назорат менамуд.

Девони сохиб-ул-барид (сардори почта) ба расонидани муросилоти давлатй маъмур буд. Аммо коркунони махаллии ин девон на фақат вази-

\footnotetext{
${ }^{1}$ Here, “. . . фақат хуамон вақт мумкин мешавад” ('. . . is possible only when') makes the sentence ". . ф. фақ̧ат хуамон вақ̆ мумкин мемавад, ки дар ин мамлакат як хукумати марказият пайдо кардае ба вучуд ояд." а possible conditional sentence. Hence, the main compound verb "ба вучууд омадан" is in present subjunctive form. See, discussion of Tajik verbs in John R. Perry, A Tajik Persian Reference Grammar (Leiden, Boston: Brill Academic Publishers: 2005).

2 “. . . риоя карда намешуд" is in passive [Past participle + the appropriate form of щудан].

з “. . . дах бинои олй барои девонхо сохта буданд.” literally translates into ". . . they had built ten large buildings for diwans." Nonetheless, an appropriate translation would be '. . . ten large buildings were/had been built for diwans'.

${ }^{4}$ The letter "й” in иқтисодй changed to "и" in иқтисодии давлат because it is written only in a word final-position.
} 
фаи хатбариро адо мекарданд, балки дар бораи хокимон ва маъмурини махаллии давлатй ва рафтори онхо хабархои махфиро хам ба марказ расонида меистоданд , яъне вазифаи маъмурони “махкамаи сиёх"-ро низ ба чо меоварданд. Девони барид бо чунин хусусияти худ аз дигар девонхо тафовут дошт, ки муассисахои махаллии вай ба хокимхо итоат нанамуда, бевосита ба идораи марказии худ нигох мекарданд. Бояд қайд кард, ки почта дар он вақтхо фақат ба эхтиёчоти давлат хидмат менамуд ва барои ахолй дастрас набуд.

Девони мухтасиб ба бозор, тарозу, молхои фурӯшии барзгарон ва пешаварон назорат мекард. Вай метавонист фурӯши молхои қалб ва номарғубро боздорад ва ба нархи гарон фуруххтани махсулотро манъ кунад. Ин девон тадричан ба ахлоқи мардум, масчидравй ва истеьмоли машрубот низ назорат мекардагй шуд. ${ }^{6}$ Шахре набуд, ки мухтасиби худро надошта бошад.

Девони мушриф корхои давлатй, хусусан харчу дахли хазинаро назорат мекард. Ғайр аз ин девонхо боз девони мулкхои давлатй, девони қозй ва девони вақф мавчуд буд. ${ }^{7}$

(Text taken from Б. Ғ. Ғафуров, Точикон (Душанбе: Дониш, 2008), 335-37)

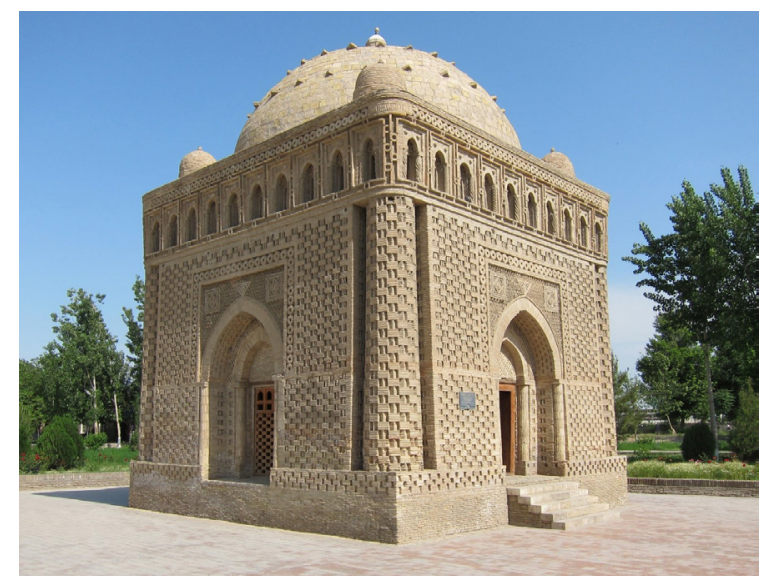

(Mausoleum of Ismail Samani, Bukhara, Uzbekistan) $^{8}$

\footnotetext{
5 'расонида меистоданд' means 'used to send'. It could also be written мерасониданд. For more see John R. Perry, A Tajik Persian Reference Grammar, 226-27.

6 'назорат мекардагй шуд' means 'began to supervise'. The мекардагй functions as non-witnessed durative. For more see Perry, A Tajik Persian Reference Grammar, 276.

${ }^{7}$ For more information on Samanids in English, see Richard N. Frye "The Samanids" in Richard N. Frye (ed.) The Cambridge History of Iran, Volume 4. Cambridge University Press: 1975.

${ }^{8}$ Mausoleum of Ismail Samani, Bukhara. Image source: Wikimedia Commons https://commons.wikimedia.org/wiki/File\%3AUZ_Bukhara_Samanid-mausoleum.jpg
} 


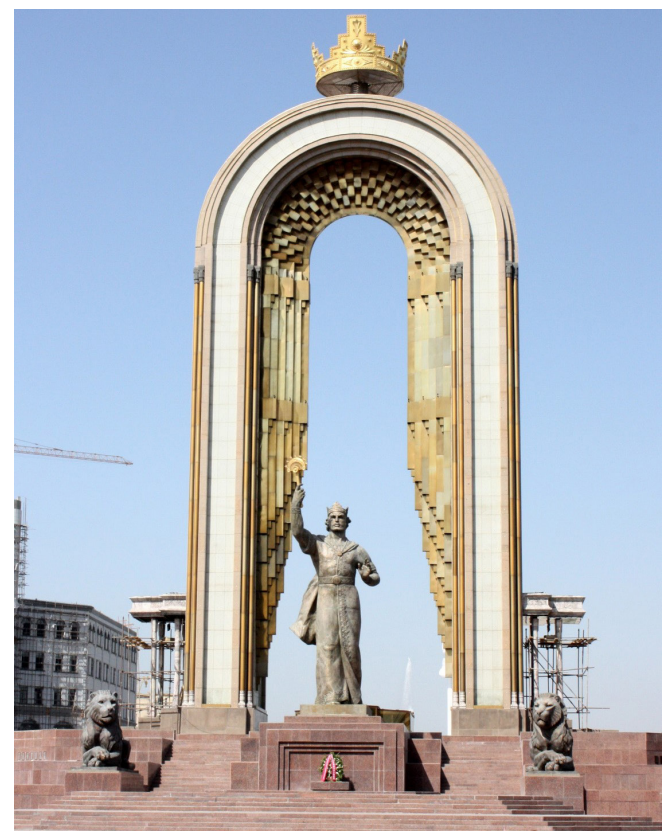

(Somoni Monument, Dushanbe, Tajikistan) ${ }^{9}$

\section{VOCABULARY}

Аз рӯи (prep.) - according to, on account of

Амид-ул-мулк (n.) - chief of the department of official documents [Lit. амид - chief, great man; мулк country]

Асосгузор (n.) - founder

Барзгар (n.) - farmer

Вақф (n.) - endowment

гражданй (adj.) - civil (a Russian loanword for шахрвандй)

Дар ихтиёри (касе) - at (someone's) disposal

Даргох (n.) - (royal) court
Дастгох (n.) - apparatus

Девон (n.) - government department, chancery

Идора (n.) - office, institution

Идора кардан (v.) - to manage

Икдомот(n.) - effort

Иқтисодй (adj.) - economic

Ихтиёр (n.) - will,

Қалб (adj.) - counterfeit, fraud

Қозй (n.) - judge

Мансаб (n.) - rank, position

Марказ (n.) - center

\footnotetext{
${ }^{9}$ Somoni Monument, Dushanbe, Tajikistan. Image source: https://commons.wikimedia.org/ wiki/File:Somoni Monument, Dushanbe, Tajikistan.JPG (Attribution: By Rjruiziii (Own work) [CC BY-SA 3.0 (http://creativecommons.org/licenses/by-sa/3.0)], via Wikimedia Commons)
} 
Махкамаи сиёх (n.) - "black room"

Маъмурй (adj.) - administrative

Муассиса (n.) - institution, foundation

Мудохила кардан (v.) - to interfere

Мулк (n.) - property; country, state

Муросилот (pl. of муросила) correspondence

Муставфй (n.) - treasurer

Мутаносиб (adj.) - appropriate

Мухтасиб (n.) - police officer, chief of police

Мушриф (n.) - inspector

Назорат (n.) - control

Номарғуб (adj.) - shoddy, of poor quality

Пешавар (n.) - craftsman

Почта (n.) - mail, post office

Регистон - public square near citadel in Samarqand and Bukhara

Салтанат (v.) - reign

Сиёсӣ (adj.) - political
Coxa (n.) - field, area, domain

Сохиб-ул-барид (n.) - chief of the postal department, postmaster

Сохиб-уш-шурот (n.) - captain of the guard [Шурта (pl. шурот) - police)]

Тақсимот (n.) - division

Тарозу (n.) - scale

Таъин шудан (v.) - to be appointed

Усул (n.) - method

Хазина (n.) - treasury

Хатбари - delivering mail

Хилофат (n.) - caliphate

харб (n.) - war, battle [adj. харбй]

харбй-гражданй - military-civil

Хочиб (n.) - chamberlain

Чи навъе ки (adv.) - as

Чุорй намудан (v.) - to implement

Шароит (n.) - condition, environment

Шаxp (n.) - city

Қозй (n.) - judge

\section{EXERCISES}

\section{Машқи 1: Чавоби дурустро интихоб намоед. (Choose the correct answer.)}

1. Икдоми асосии асосгузори давлати Сомониён Исмоили Сомонй чй буд?
a) забт кардани кишвархои хамсоя
b) марказонидани идораи давлати худ
c) таъмин намудани мардум бо чои кор

2. Дар замони Сомониён чанд идораи марказй буд?
a) панч
b) шаш
c) дах 
3. Кй ба тамоми куввахои харбии давлат назорат мекард?

a) девони сохиб-уш-шурот

b) подшох

c) хочиби бузург

4. Девони сохиб-ул-барид чй вазифаро ичро мекард?
a) сардори лашкар
b) сардори почта
c) хокими шахр

5. Масъулияти назорати харчу дахли хазинаро кудом девон дошт?

а) девони мушриф

b) девони мулкхои давлатй

c) девони қозй

Машқи 2: Калимахои хаммаъноро мувофиқат намоед. (Match the synonyms in the following table.)
1. Мутаносиб
2. Шароит
3. Мансаб
4. Хазина
5. Чорй намудан

$\begin{array}{cl}\text { ○ } & \text { мақом } \\ \circ & \text { мувоффиқ } \\ \text { ○ } & \text { мали намудан } \\ \circ & \text { вазъият } \\ \circ & \text { ганчина }\end{array}$

Машқи 3: Барои чумлахои дуруст харфи [Д], ва барои чумлахои нодуруст харфи [Н] - ро интихоб намоед? (Choose [Д] for the true statements and $[\mathrm{H}]$ for the false.)

1. Дар асри $\mathrm{X}$ зарурати марказонидани давлат вучуд надошт. [Д/H]

2. Хамаи корхои молиявии мамлакат ба уухдаи Девони муставфй вогузор шуда буд. [Д/Н]

3. Дар давлати Сомониён сохторхои идоракунии давлат пароканда буданд. [Д/Н]

4. Вазифаи Девони мушриф як қатор корхои давлатй, бахусус харчу дахли хазинаро назорат мекард. [Д/Н]

5. Девони сохиб-уш-шурот ба бозор, тарозу, молхои фурӯшии барзгарон ва пешаварон назорат мекард. [Д/Н] 
Машқи 4: Чумлахоро мувофиқи маъно/замон бо истифода аз калимахои дар қавс оварда шуда ба охир расонед. (Complete the following sentences with the appropriate word/form of the verbs in parenthesis.)

1. Девони амид-ул-мулк яке аз вазифахояш ин буд, ки дипломатиро бо дигар мамлакатхо идора мекард. (робитахо/ватандӯстй)

2. Дар ахди Сосониён дастгохи давлатй ба даргох ва девонхо тақсим (ичро мекарданд/мешуданд).

3. Гвардияи Сомониён дар зери итоати Девони сохиб-ушшурот . (будан/чанг кардан)

4. Мансабдорони шинохтаи дарбор одатан ба вазифахое , ки вазифаи ин ва ё он девон ба шумор мерафт. (даст задан/хунукназарй кардан)

5. Девони мухтасиб ба ахлоқи мардум, масчидравй ва истеьмоли низ назорат мекардагй шуд. (нӯшокихои масткунанда/ хуррокхои хоричй) 


\section{CHAPTER 2: STATUES OF BUDDHA}

\section{мучассамахои буддой}

Баъзе асархои санъати хайкалтарошй дар осорхои гуногун дучор мешаванд. Дар Ачинатеппа як силсила мучассамахои буддой ба даст омад. Тамоми хайкалхои буддой аз лой буда, аз дарун қафасаи чуббин ${ }^{1}$ надоранд. Қисмхои калони хайкал аз лой сохта шуда, чузъиёти он бо қолаб тайёр карда мешуд. Сари хайкалхои андозаашон хурд ва миёна бо қолаб сохта, аз нууги по то фарқи сари хайкалхо ранг дода мешуд. Сарулибоси Буддоро сурх, дасту пояшро сафед, ва мӯяшро кабуд ё сиёх мекарданд.

Калонтарин хайкали ин мачмӯа хайкали Буддо дар холати нирвана аст. Ин хақиқатан як мучассамаи бенихоят бузург мебошад, вале он рост наистода, балки дар суфаи таги девор дароз кашидааст. Хайкал ба пахлуи рост хобидааст, дасти чапашро дароз карда, ба пахлу гузоштааст. Дасти росташ қат буда, дар таги сараш мебошад ва дасту сар дар болои болиштаки панчқисма қарор гирифтааст. Ба андозаи хайкал хамин далолат мекунад, ки дарозии кафи пои он 1,7-1,9 м мебошад. Худи хайкал аслан 12 м будааст. Рӯи бадани Буддоро қатхои либоси сурх пушшдааст, фақат панчаи даст ва пой луч мондааст. Дар пои Буддо кафши сабуке будааст, ки онро бо тасма ба пойхо мебастаанд. Фақат баъзе қисмхои сар боқй мондааст. Мӯйсари Буддо чолиби диққат аст-хар як тори онро мавцุвор шона зада хеле шинам хобонда мондаанд. Агар дар санъати буддой хайкали Буддо тасвир шавад, он одатан дар холати нирвана - якпахлу гузошта мешуд ва дар ин сурат хайкалтарошони буддой, хатто харакат намекарданд, ки хусусияти аъзои бадани каси хобидаро аниқ тачассум намоянд. Тасаввур кардан душвор нест, ки ин хайкал 13 аср пеш чи таъсири азиме дошт ва буддоиёни мутътақидро то чи андоза моту мабхут мекард. Аз дигар хайкалхои Буддо хайкалхоеро ном бурдан даркор, ки дар тоқчахо истодаанд. Онхо нисбат ба Буддои хуфта хеле хурд, вале аз қади одам 1,5 баробар калонтар мебошанд. ${ }^{2}$

(Text taken from Б. Ғ. Ғафуров, Точикон (Душанбе: Дониш, 2008) 242)

\footnotetext{
${ }^{1}$ The prefix -ин is added to a noun to make adjective. Here чуубин (wooden) is derived from the word чўб.

${ }^{2}$ For modern Tajik art and architecture see, Larisa Dodkhudoeva, Rustam Mukimov, and Katherine Hughes, "Tajik Art: A Century of New Traditions" in The Shaping of Persian Art Collections and Interpretations of the Art of Islamic Iran and Central Asia, ed. Yuka Kadoi and Iván Szántó (Newcastle upon Tyne, England: Cambridge Scholars Publishing, 2013).
} 


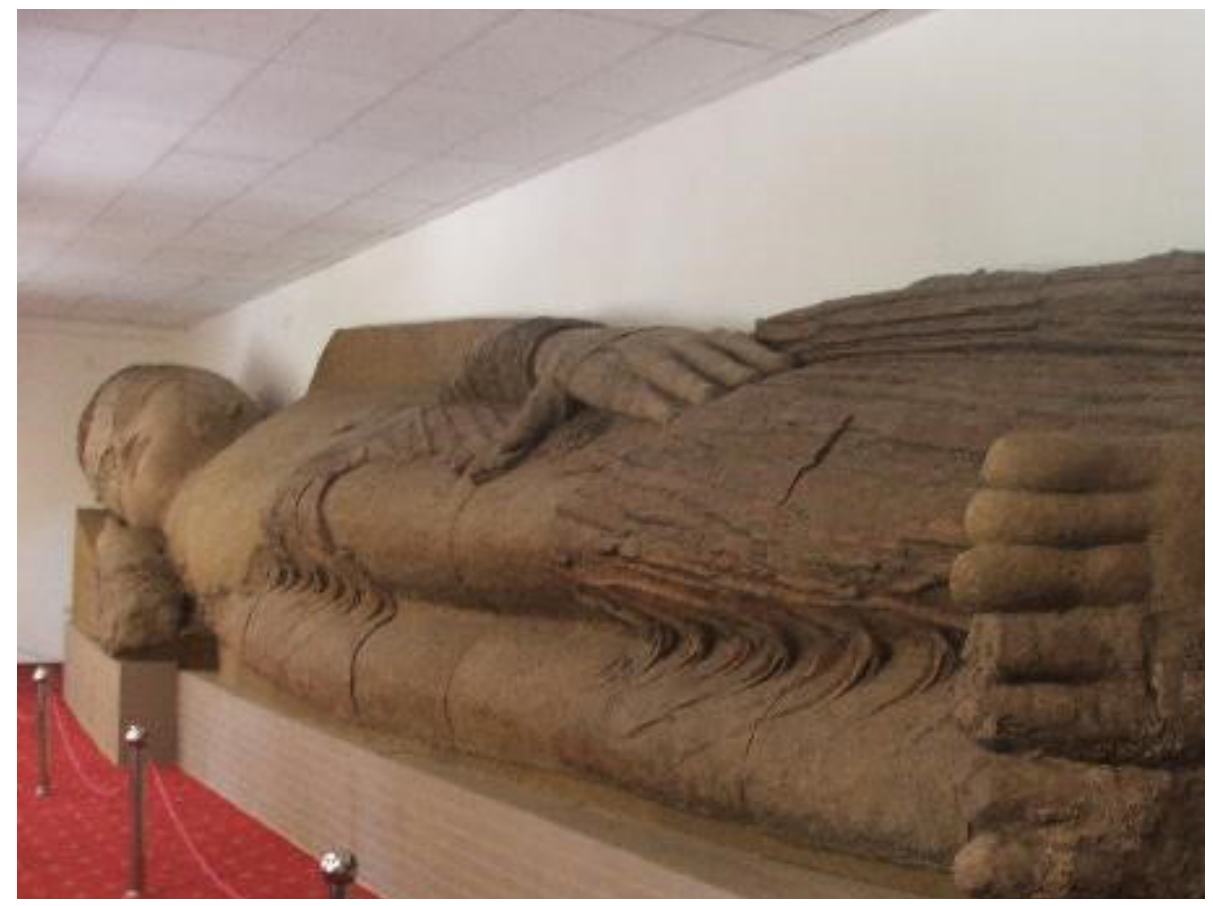

\section{VOCABULARY}

Андоза (n.) - size, measurement, degree

Acap (n.) |acapxo, ocop $\mid$ - work of art, monument, composition (of writers)

Боқи мондан (v.) - to remain, to be left

Болиштак (n.) - cushion, pillow

Буддои хуфта - sleeping/reclining Buddha

Дучор шудан (v.) - to come across, to be met with

Кабуд (adj.) - blue; green (as in чойи кабуд 'green tea')

кандакорй (n.) - engraving, carving

Қат (n.) - curve, crease, fold

Қисм (n.) - part
Қолаб/қолиб (n.) - mold, cast

Либос (n.) - cloth

Лой (n.) - clay

Луч (adj.) - bare, naked

Мавчвор (adj.) - wavy, wave - like

Мачмӯa (n.) - collection, series

Мȳйcap (n.) - hair (of head)

Нирвана (n.) - nirvana

Пахлу (n.) - side

Рост истодан (v.) - to stand straight

Сабук (adj.) - light

санъат (n.) - art

Сиёх (adj.) - black

Силсила (n.) - series 
Cуфа (n.) - platform

Тасаввур кардан (v.) - to imagine

Тасма (n.) - strap, belt

Тоқча (n.) - niche

Хайкал (n.) - statue

Хайкалтарошй (n.) - art of sculpture, sculpting хайкалхои буддой - statues of Buddha

Харакат кардан (v.) - to aspire

Чӯб (n.) - wood

Шинам - well-fitting [либаси шинам 'well-fitting dress]

\section{EXERCISE}

Машқи 1: Чавоби дурустро интихоб намоед. (Choose the correct answer.)

1. Дар Ачинатеппа чй намуди санъат дарёфт шуд?
a) хайкалхои буддой
b) санъати тасвирй
c) кандакорй

2. Хайкали Буддо дар кадом холат пайдо карда шуд?
a) дар холати рост истода
b) дар холати хобида
c) дар холати нишаста

3. Хайкалхо одатан аз кадом намуди масолеххо сохта мешуданд?
a) лой
b) чӯб
c) санг

4. Дарозии хайкали мазкури Буддо чй қадар аст?
a) аз қади одам якуним метр дарозтар
b) сездах метр
c) дувоздах метр

5. Ин асархои хайкалтарошй ба кадом аср мансубанд?
a) сездахум
b) дувоздахум
c) хафтум 
Машқи 2: Калимахои хаммаъноро мувофиқат намоед. (Match the synonyms in the following table.)

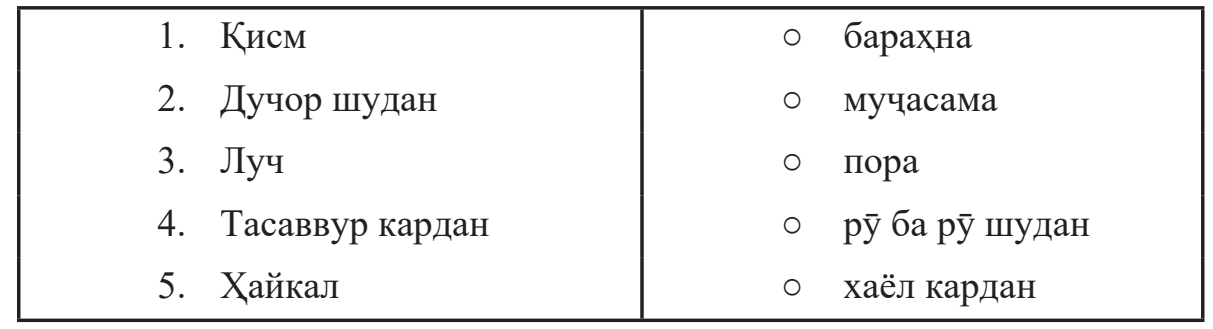

Машқи 3: Барои чумлахои дуруст харфи [Д], ва барои чумлахои нодуруст харфи $[\mathrm{H}]-$ ро интихоб намоед? (Choose [Д] for the true statements and $[\mathrm{H}]$ for the false.)

1. Хайкалхои буддой аз лой сохта шуда, аз дарун бо қафасаи чуббин мустахкам карда мешуданд. [Д/Н]

2. Аз хама бузургтарин хайкали Буддо дар Осиёи Миёна дар Ачинатеппаи Точикистон дарёфт шудааст. [Д/Н]

3. Буддои хуфта ва дигар хайкалхои Буддо дар холати нирвана омода шудаанд. [Д/H]

4. Хайкалтарошон кӯшиш мекарданд, ки дар пойхои Буддо кафшхои қашангу вазнин тачассум намоянд. [Д/Н]

5. Кандакорон танхо сари Буддоро урён тачассум мекарданд. [Д/H]

Машқи 4: Чумлахоро мувофиқи маъно/замон бо истифода аз калимахои дар қавс оварда шуда ба охир расонед. (Complete the following sentences with the appropriate word/form of the verbs in parenthesis.)

1. Дар Ачинатеппа Буддои хуфтаи дувоздахметра (аз байн бурдан /дарёфт шудан).

2. Намуди зохирии Буддоро рангу бор дода мӯйи сарашро тасвир менамуданд. (сиёх ё кабуд/ кандакорӣ)

3. Дар он замон намуди хайкалхои Буддо низ вучуд дошт, ки на он қадар калон буда дар тоқчахо меистодаанд. (одатан/дигар) 
4. Дар санъати буддой хайкалхои Буддо одатан дар холати як пахлу ___ (дууст доштан/нишон додан).

5. Колонтарин қисматхои мучассама аз лой чузъиёти он бо қолаб тайёр карда мешуд. (иборат будан/тақсим шудан) 


\section{CHAPTER 3: ABŪ ABDULLĀH RŪDAKI}

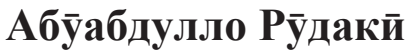 \\ $(858-941)$}

Таърихи хазорусадсолаи адабиёти навини точик, ки давоми бевоситаи адабиёти қадими он аст, бо номи асосгузори он устод Рӯдакй вобаста мебошад. Руддакиро муосиронаш ва суханварони баъдина бо унвонхои ифтихории қофиласолори назми форс, сохибқирони шоирй, устоди шоирон, султони шоирон ва одамушшуаро ёд мекунанд. Дар давоми ёздах асри мавчудияти адабиёти точику форс анъанахои Рудакй хамеша зиндаву човидон буданд. Имрӯз хам шухрат, манзалат ва эхтироми устод Рўдакй оламгир аст.

Соли 858 дар яке аз дехахои зебоманзари водии Зарафшон, Рӯдак, модари хушбахте писаре зод, ки номи уро Чаъфар ниходанд. Бо мурури замон ва гузашти айём ин кӯдак ба дарачаи бузургтарин мардони номвари чахонй шинохта шуд. Номи пурраи Руддакй ва падару бобоёни уे чунин аст: Абуабдулло Чаъфар ибни Мухаммад ибни Хаким ибни Абдурахмон ибни Одам. ${ }^{1}$ Чаъфар номи аслии усст, ки падару модар ба вай ин номро гузоштаанд. Абуабдулло номи эхтиромии усст. Ин гуна ном барои одамони баобру, хусусан олимону шоирон баъди ба камол расидан ва шуххрат ёфтани онхо гузошта мешуд. ${ }^{2}$ Мухаммад номи падари Чаъфар буд, Хаким ва Абдурахмону Одам бобокалонхои Чаъфар буданд. Рӯдакй тахаллуси шоирии устод аст, ки аз номи дехаи зебои дурдасти худ Рӯдак гирифтааст. ${ }^{3}$

(Text taken from Аълохон Афсахзод, Адабиёти Точик (Grade 8 History Textbook, Tajikistan) Pleiades Publishing Inc. 2001)

\footnotetext{
${ }^{1}$ One of the traditional practices in Muslim societies, now mostly confined to the Arab world, is to call a person 'the father of so-and-so' or 'mother of so-and-so' by using the words $A b u$ (father of) or Umm (mother of) respectively. Such names are called kunya. For example, Abu Hanifa means 'father of Hanifa' and Umm Kulthum 'mother of Kulsum'. A person can also be called by his/her nasab (pedigree, genealogy) as ibn X 'son of so-and-so' or bint X 'daughter of so-and-so". Arabic words ibn and bint means 'son' and 'daughter' respectively. The full name may comprise the kunya, the name given by parents at birth, and nasab. So, in Rudaki's full name as given in the text, Абуабдулло is his kunya, Чаъфар his original name at birth, and ибни Мухаммад ибни Хаким ибни Абдурахмон ибни Одам nasab (consisting of four generations). For a scholarly discussion of naming practices in Muslim societies, see Annemarie Schimmel, Islamic Names (Edinburgh : Edinburgh University Press, 1995) and for a brief discussion see https://cmes.uchicago.edu/sites/cmes.uchicago.edu/files/uploads/Traditional\%20Muslim\%20 Names.pdf

${ }^{2}$ Passive: past participle of the main verb + the appropriate tense of mydaн 'to be/become'.

${ }^{3}$ For more information on Rudaki in English, see https://www.britannica.com/biography/Rudaki ; for Classical Persian literature see http://www.iranicaonline.org/articles/iran-viii2-classical-persian-literature.
} 
Намунае аз осори Рӯдакй:

\title{
Бӯи Чӯи Мӯлиён
}

\author{
Бӯи Чууи Мӯлиён ояд хаме, ${ }^{4}$ \\ Ёди ёри мехрубон ояд хаме. \\ Реги Омуву дурушти рохи $\bar{y}$, \\ Зери поям парниён ояд хаме. \\ Оби Чайхун бо хама пахноварй, \\ Хинги моро то миён ояд хаме. \\ Эй Бухоро, шод бошу дер зй, \\ Мир наздат шодмон ояд хаме. \\ Мир мох асту Бухоро осмон, \\ Мох суии осмон ояд хаме. \\ Мир сарв асту Бухоро бӯстон, \\ Сарв суии бусстон ояд хаме.
}

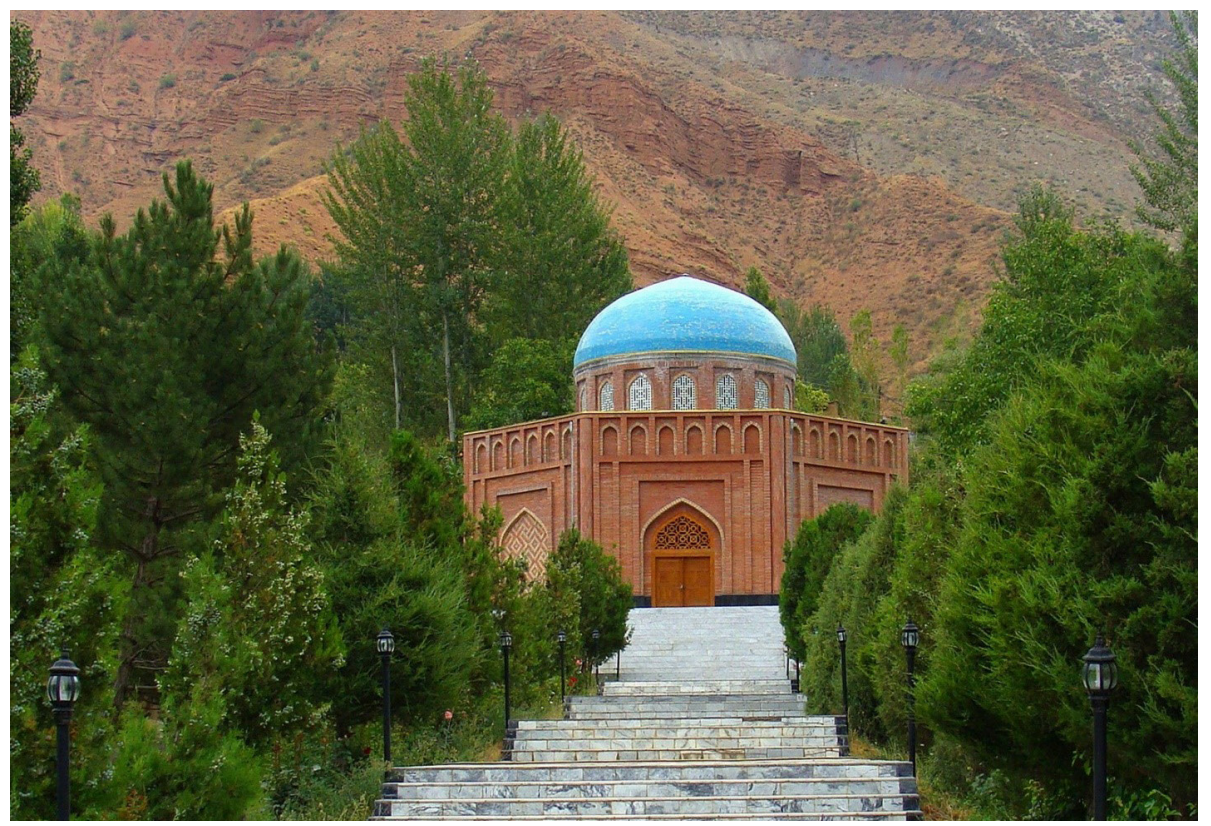

Rudaki Tomb in Panjkent, Tajikistan ${ }^{5}$

\footnotetext{
${ }^{4}$ In Classical Persian, it was common to use xame in place of me- for the habitual/continuous tense. So, хуме ояд is the same as меояд 'comes/is coming'.

${ }^{5}$ Rudaki Tomb in Panjkent. Image source: https://commons.wikimedia.org/wiki/File\%3ARudaki Tomb in Panjkent-after restored.jpg (Attribution: By MyName (Jamal Nazareth (talk)) (Own work) [CC BY 3.0 (http://creativecommons.org/licenses/by/3.0)], via Wikimedia Commons)
} 


\section{VOCABULARY}

Абу (n.) - father of

Анъана (n.) - tradition

Асосгузор (n.) - founder

Бевосита (adj.) - direct

Вобаста будан (v.) - to depend on, to be connected with

Водй (n.) - valley

Гузашти айём - with the passage of days

Давом - continuation, endurance, persistence

Дурушт (adj.) - Rough, coarse

Ибни - son of

Ифтихорй - honorary

Қофила (n.) - caravan

Қофиласолор (n.) - leader (literal: leader of a caravan)

Муулиён (n.) - name of a river in Bokhara

мурури замон - with the passage of time
Одамушшуаро - Adam of poets

Оламгир (adj.) - universal, spread throughout the world

Омӯ (n.) - the river Oxus

Парниён (n.) - silk пурра (adj.) - complete

Рег (n.) - sand, gravel,

Сарв (n.) - cypress-tree

Солор (n.) - leader

Сохибқирон (adj.) - fortunate, lucky, invincible hero (a title usually given to mighty sultans and kings)

Тахаллус (n.) - a pen name, a nom de plume

Унвон (n.) - title

Хинг (n.) - a gray horse

Чайхун (n.) - the river Oxus (or river Bactrus)

Чұовидон (adj.) - everlasting, perpetual

\section{EXERCISES}

\section{Машқи 1: Чавоби дурустро интихоб намоед. (Choose the correct answer.)}

1. Рӯдакй асосгузори адабиёти точику форс кай таваллуд шудааст?

a) соли хафсаду панчоху хафт

b) соли панчсаду панчоху шаш

c) соли хашсаду панчоху хашт

2. Номи аслии шоир чист?
a) Чаъфар
b) Абдурахмон
c) Руддакй 
3. Руддакй- тахаллуси шоир аз кучо пайдо шудааст?
a) номи устоди шоираст
b) номи мадрасаи шоираст
c) номи дехаи шоираст

4. Устод Абуабдулло Рӯдакй дар кадом яке аз водихои зебоманзари Точикистон ба дунё омадааст?
a) дар водии Хисор
b) дар водии Зарафшон
c) дар водии Рашт

5. Падари Абӯабдулло Рӯдакй чй ном дошт?
a) Мухаммад
b) Одам
c) Хаким

Машқи 2: Калимахои хаммаъноро мувофиқат намоед. (Match the synonyms in the following table.)
1. Солор
○ комиЛ
2. Парниён
○ тифл
3. Бевосита
$\circ$ рохбар
4. Куудак
○ мустақим
5. Пурра
○ абрешим

Машқи 3: Барои чумлахои дуруст харфи [Д], ва барои чумлахои нодуруст харфи [H] - ро интихоб намоед? (Choose [Д] for the true statements and $[\mathrm{H}]$ for the false.)

1. Абӯабдулло Рӯдакиро муосиронаш султони шоирон ва одамушшуаро мегуфтанд. [Д/Н]

2. Хамаги давоми чор асри мавчудияти адабиёти форсу точик эчодиёти Руддакй хамеша зиндаву човидон монд. [Д/Н]

3. Бо гузашти замон имрӯз Чаъфарро яке аз бузургтарин мардони номвари чахонй мешиносанд. [Д/Н]

4. Мардуми Бухоро боял шод бошанд чун амир ба ончо меравад. [Д/H] 
5. Абуабдулло номи аслии ин шоири бузургаст, ки волидайнаш ба уे номгузорй карда буданд. [Д/Н]

Машқи 4: Чумлахоро мувофиқи маъно/замон бо истифода аз калимахои дар қавс оварда шуда ба охир расонед. (Complete the following sentences with the appropriate word/form of the verbs in parenthesis.)

1. Дар водии Зарафшон, соли 858 оилаи хушбахте писаре ба дунё овард, ки урро имрӯз асосгузор ва падари точикй меноманд. (таърихи/шеъри)

2. Устод Абуабдулло Рӯдакиро мардуми точику форс хамчун устоди ёд мекунанд. (шоирон/варзишгарон)

3. Адабиёти точику форс дар давоми асрхои зиёди мавчудияташ ашъори)

4. Номи эхтиромии шоир Абӯабдулло баъди ба камол расиданаш шуд. (гузошта/ном)

5. Мох ба самти осмон . (омадан/ларзидан) 


\section{CHAPTER 4: RUSSIAN OCCUPATION OF CENTRAL ASIA}

\section{Забти Осиёи Миёна аз тарафи Русия}

Осиёи Миёна дар арафаи забти Русия иборат аз 3 хонигарй (Бухоро, Хоразм ва Кўқанд) иборат буд. Вале, дар водии Зарафшон, нохияхои марказии Точикистони имрӯза ва Помир мулкхои мустақил ва ниммустақил хам вучуд доштанд. Ғуломдорй ва ғуломфурӯшй дар ин хонигарихо то ба забти Русия ва баъд аз он то солхои 1885-87 вучуд доштанд. Баъд аз бекор кардани хукуқи крепостной соли 1861 дар Русия рушди сармоядорй бо суръати тез пеш меравад ва бояд корхонахои саноатии он бо ашъёи хом таъмин мешуданд. ${ }^{1}$

Бинобар ин Осиёи Миёна хамчун кишвари аз сарватхои зеризаминй бой кайхо боз диққати мамлакатхои капиталистиро ба худ чалб намуда буд. Дар навбати аввал барои ба мустамликаи худ табдил додани Осиёи Миёна подшоххои Русия ва Англия мубориза мебурданд². Султони Туркия ва шохи Эрон хам тайёр буданд, ки ягон порча замини Осиёи Миёнаро ишғол намоянд. Ин давлатхо аз солхои 20-уми асри XIX сар карда ба корхои дохилии хонигарихои Осиёи Миёна фаъолона дахолат мекарданд. Онхо ба ин чо чосусони худро фиристода, ба манфиати Англия бар зидди Русия амалиёт мегузарониданд.

Туркхо сиёсати пантуркй ва эрониён сиёсати панисломиро дар Осиёи Миёна пурзуур карданд. Дар солхои 50-60-уми асри XIX англисхо дар Хиндустон мавқеи ${ }^{3}$ худро бисёр мустахкам карда ${ }^{4}$, нақшаи забт кардани Осиёи Миёна ва Афғонистонро кашиданд. Аз миёнаи асри XIX сар карда ба бозорхои Осиёи Миёна молхои англисй дохил шуда, молхои Русияро танг карда бароварданд. Хамин тариқ, тахдиди дар зери асорати Англия афтодани Осиёи Миёна ва хавфи кам шудани доду гирифти ин кишвар бо Русия ба миён омад. Ин вазъият мачбур сохт, ки Русия нақшаи забт кардани Осиёи Миёнаро зудтар ба ичро расонад.

Солхои 1862-1863 куушунхои рус амалиёти чосусй гузаронида, якчанд истехкомхоро забт намуданд ва сентябри соли 1864 дар ду фронт аз тарафи Оренбург ва Авули Ато бо сардории генерал Черняев ба хучуми қатъи гузашта, Чимкентро ишғол намуданд ва ба тарафи Тошканд равона шуданд. Пас аз ду хучуми қатъй 17 маи соли 1865 Тошканд ба дасти русхо гузашт. Баъди забти Тошканд кушшуни рус хучумро давом дода, 25 майи соли 1866 Хучанд ва 2 октябри хамон сол Уротеппаро ишғол кард. Русхо дар ин чо як дастаи худро гузошта, дар зери фармондехии

\footnotetext{
${ }^{1}$ The grammatical construction бояд + past imperfect denotes obligation in the past. For example, бояд мехарид 'he had to buy/he should have bought'.

2 'мубориза мебурданд' (contested/used to contest) is in habitual past tense.

${ }^{3}$ The word Мавқеь loses its glottal stop ь before и in ezafeh construction.

4 ‘мавқеи худро бисёр мустахкам карда' means 'having strengthened (their) position'.
} 
Романовский ба Чиззах хамла карданд. Чиззах 18 октябри соли 1866 таслим шуд ва амири Бухоро Музаффар аз он чо гурехт. Соли 1868 байни хукумати Русия ва хонигарии Кууқанд сулхнома баста шуд, ки мувофиқи он хонигарии Қўқанд худро тобеи Русия подшохй медонист. ${ }^{5}$

(Text taken from Исмоилова Б.И., Таърихи Халқ̧и Точџик, Хучанд: Ношир, 2005, 61-64)

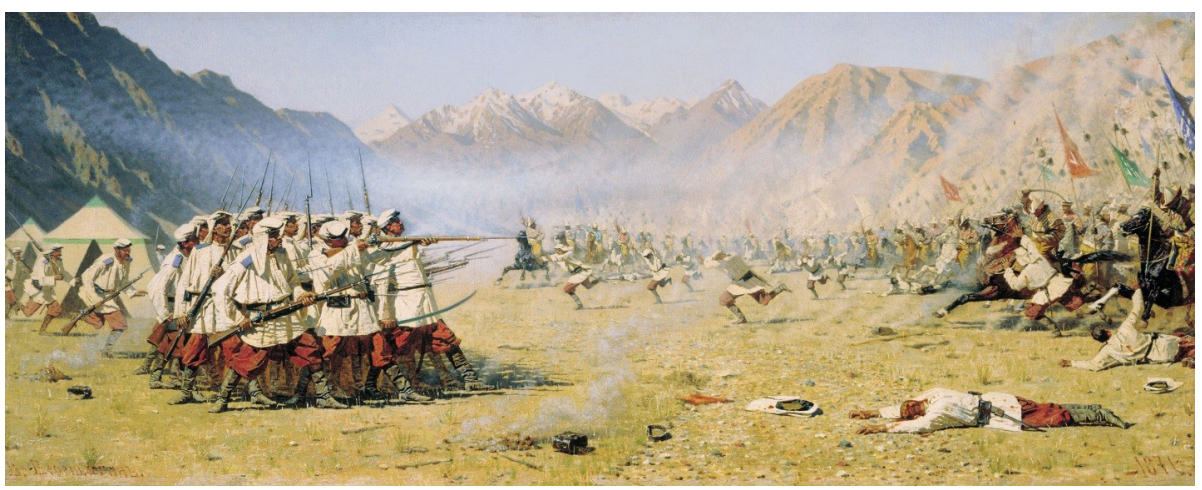

(Russian War of Occupation: They Attack Unaware) ${ }^{6}$

\section{VOCABULARY}

Амалиёт (n.) - activities , operation

Apaфa (n.) - eve, period before an event; ninth day of the Arabic month zul hijja

Acopat (n.) - captivity

Ашёи хом - raw materials

Баровардан (v.) - to take out

Ғуломдорй (n.) - system of slave owning

Ғуломфурушшй - selling of slaves, slave trade

Дар арафаи - on the eve of
Дахолат кардан (v.) - to intervene доду гирифт (also written as додугирифт) (n.) - trade, trading relations, barter

Забт кардан (n.) - conquer

Забти Осиёи Миёна (n.) - Occupy of Central Asia

Истехком - fortification, defensive work

Ишғол кардан (v.) - to оссиру

Кайхо (adv.) - long ago, since long

Кайхо боз - very long ago, already long ago

\footnotetext{
${ }^{5}$ For more on this topic, read Peter Hopkirk, The Great Game: The Struggle for Empire in Central Asia (New York: Kodansha, 1994)

6 "They Attack Unaware" Image source: https://commons.wikimedia.org/wiki/File:Wassilij Wassiljewitsch Wereschtschagin 002.jpg (Attribution: Vasily Vereshchagin [Public domain or Public domain], via Wikimedia Commons)
} 
Корхонахои саноатй - industrial enterprises, factories

Крепостной (n.)- serf

Кӯшун (n.) - army, troops

Мавқеъ (n.) - position; place, location

Манфиат (n.) - interest, profit, gain

Мубориза бурдан (v.) - to fight, to struggle

Мустақил (adj.) - independent

Мустамлика (n.) - colony, settlement

Пурзурр кардан (v.) - to strengthen

Сарватхои зеризаминй - mineral resources
Сардор (n.) - leader

Сармоядорй (n.) - capitalism

Сиёсат (n.) - policy, politics

Сулх бастан - to sign a peace treaty

Фармондех (n.) - commander

Фаъолона (adv.) - actively

Фронт - front

Хонигарӣ (n.) - Khanate

Хучуми қатъй - serious attack

Чุосусй (n.) - espionage

Шурриш (v.) - revolt

\section{EXERCISES}

\section{Машқи 1: Чавоби дурустро интихоб намоед. (Choose the correct answer.)}

1. Дар Осиёи Миёна чй диққати давлатхои капиталистиро ба худ чалб намуда буд?

a) ғуломон

b) корхонахои саноати

c) сарватхои зеризаминй

2. Кадом давлатхо Осиёи Миёнаро барои ба мустамликаи худ даровардан мубориза мебурданд?
a) Олмон ва ИМА
b) Хиндустон ва Афғонистон
c) Англия ва Руссия

3. Осиёи Миёна дар арафаи забти Руссия аз чанд хонигарй иборат буд?
a) 5
b) 3
c) 8

4. Кадом сол кушшунхои Руссия забт намудани Осиёи Миёнаро сар карданд?
a) 1862
b) 1864
c) 1866 
5. Кӯшунхои рус баъд аз забти Тошкант, пойтахти имрӯзаи Ўзбакистон кадом минтақаи Точикистонро ба зери тобеи худ дароварданд?
a) Помир
b) Хучанд
c) Хатлон

Машқи 2: Калимахои хаммаъноро мувофиқат намоед. (Match the synonyms in the following table.)

\begin{tabular}{|l|l|}
\hline 1. Забт & $\circ$ рохбар \\
2. Мустақил & $\circ$ фоида \\
3. Сардор & $\circ$ чойгох \\
4. Манфиат & $\circ$ озод \\
5. Мавқеь & $\circ$ ишғол \\
\hline
\end{tabular}

Машқи 3: Барои чумлахои дуруст харфи [Д], ва барои чумлахои нодуруст харфи $[\mathrm{H}]$ - ро интихоб намоед? (Choose [Д] for the true statements and $[\mathrm{H}]$ for the false.)

1. Аз сабаби бой будани аз сарватхои зеризаминй, хонигарихои Осиёи Миёна давлатхои пурқуввати ин минтақаро шикаст доданд. [Д/Н]

2. Султони Туркия ва шохи Эрон ба корхои дохилии хонигарихои Осиёи Миёна ахамият надода, дахолат хам намекарданд. [Д/H]

3. Дар солхои 50-60-ум Хиндухо мавқеи худро мустахкам намуда, нақшаи забт кардани Осиёи Миёнаро кашиданд. [Д/H]

4. Дар бахори соли 1865 , русхо хамагй бо ду хамлаи шадид Тошкандро дар зери асорати худ дароварданд. [Д/Н]

5. Мутаасифона дар соли 1868 аз сабаби бад будани вазъияти Русия, хукумати Русия бо хонигарии Кўқанд ахдномаи сулхро баста натавонист. [Д/Н] 
Машқи 4: Чумлахоро мувофиқи маъно/замон бо истифода аз калимахои дар қавс оварда шуда ба охир расонед. (Complete the following sentences with the appropriate word/form of the verbs in parenthesis.)

1. Пеш ва баъд аз забт намудани Осиёи Миёна тарафи Русия, хариду фуруши одамон хамчун ғулом то солли 1887 давом кард. (дар \аз)

2. Рохбарони Эрону Туркия мехостанд, ки қисмате аз Осиёи Миёна бархурдор бошанд. (тичорати। замини)

3. Пеш аз ба зери итоати худ даровардани Осиёи Миёна рохбарони Англия ва Русия . (мубориза бурдан/ парвоз кардан).

4. Куушунхои рус баъд аз забт намудани Тошканд хучумашонро ба охир нарасонида Хучанд ва Урротеппаро низ (озод намуданд\ишғол намудан)

5. Байни рохбарияти Русия ва хонигарии Қууқанд дар соли 1868 сулхнома . (баста шудан \бурда шудан) 


\section{CHAPTER 5: MIRZO TURSUNZODA}

\section{Мирзо Турсунзода \\ (1911-1977)}

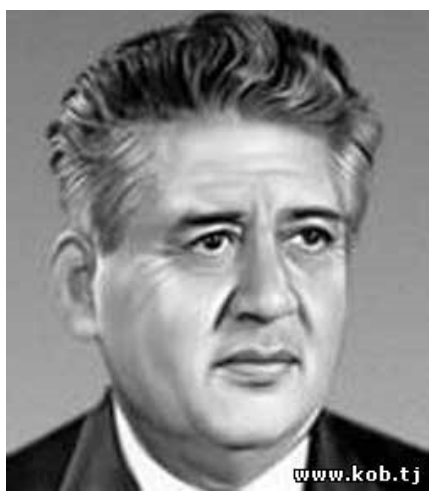

Мирзо Турсунзода дар гузари Чармгарони дехаи Қаратоғ ба дунё омадааст. Мохи майи соли 1911 дар хонадони Турсунмуроди хунармарду фархангдӯст писар ба дунё омад. Падар тифли навзодро Мирзо ном ниход ва ба тарбияи фарзанд машғул шуд.

Соли 1920 минтақаи Хисорро бемории вабо фаро гирифт. Ин офат модари Мирзо Холбибиро низ ба коми марг кашид. Мирзо хамагй нухх сол дошт, ки аз мехрубониву навозиши модар махрум монд:

Тифл мондам аз ту, модар, руйй ту дар ёд нест, Қомати ту, чашми ту, абруйи ту дар ёд нест. Дар суроғат мезанам худро ба хар як кӯю дар ${ }^{1}$, Чунки то имрӯз, модар, кӯйи ту дар ёд нест...

Тарбияи баъдии Мирзо пурра ба зиммаи падар вогузор мешавад. Шоири оянда чанд муддат дар мадрасаи назди дехаи худ ба тахсили ибтидой мепардозад. Баъди таъсиси Чумхурии мухтори Точикистон (1924) дар мамлакат мактабхои усули нав мавқеъ пайдо мекунанд. Чунин мактаб дар Қаратоғ соли 1925 ба фаъолият пардохт ва Мирзо яке аз аввалин толибилмони ин мактаб буд. Мирзо соли 1926 ба Душанбе омада, дар сафи толибилмони интернат қарор мегирад. Маъмурияти интернат Мирзоро соли 1927 хамрохи як гурӯх чавонони лаёқатманд ба Дорулмуаллимини Тошканд мефиристад.

Чор соли тахсил дар Дорулмуаллимини Тошканд ва вохӯрй бо устод Айни барин шахсиятхои фархангй дар такмили чахонбинй ва маърифатшиносии Мирзо мусоидати комил намуд. Соли 1930 Мирзо Турсунзода дар асоси роххати Кумитаи марказии комсомол ба Душанбе бармегардад ва дар руузномаи “Чавонони Точикистон” аввал ба сифати ходими адабй ва баъдан чун котиби масъул фаъолият мекунад.

Соли 1933 Мирзо Турсунзода аз падар махрум гардид. Солхои пурдахшати сиюм адиб ${ }^{2}$ аз руйи зарурат як муддат Душанберо тарк карда, дар Хучанд истиқомат мекунад. М.Турсунзода солхои 1934-35 дар

\footnotetext{
${ }^{1}$ When $ю$ is attached to a word ending in vowel sound $\check{u}$, the letter $\check{u}$ is dropped. So, кӯй + ю is written as кӯю.

${ }^{2}$ The word $а д и б$ in this sentence refers to Tursunzoda.
} 
Театри мусиқию мазхакаи шахри Хучанд вазифаи мудири қисми адабиро ба уухда доштааст. Соли 1934 хангоми ба сахна гузоштани песаи "Маликаи Турандот" ба хунарпешаи театри мазкур Сабохат Низомиддинова муносибати дӯстй пайдо карда, бо ӯ издивоч мекунад.

М.Турсунзода соли 1936 ба Душанбе омад ва то соли 1946 дар вазифахои гуногуни адабиву рӯзноманигорй фаъолият кардааст. Соли 1946 раисии Иттифоқи нависандагони Точикистонро ба уххда гирифт ва то охири умр ин вазифаро пеш бурд. Аз соли 1946 сар карда М.Турсунзода хамеша намояндаи халқ дар парлумони шурравй буд ва шоир ${ }^{3}$ дар пахлӯи корхои эчодй ба тамоми хастй фаъолияти чамъиятии хешро хам идома медод.

(Text taken from Худойназар Асозода and Аламхон Куччаров, Адабиёти Точุик (Grade 11 literature textbook), 2007. 161-163)

Намунае аз осори Турсунзода:

\section{"ВАТАН"}

Бахор омад, зи умрам боз як соли дигар бигзашт, Тамоми зиндагй охиста аз пеши назар бигзашт. Ба мисли гӯшту нохун ман хамеша бо Ватан будам, Агарчи нисфи умри бехтаринам дар сафар бигзашт.

Ватан, дар хар кучо омад ба сар форам хавои ту,

Ман аз он сӯи уқёнус бишнидам садои ту, Агарчи дар миён тӯфону мавчи бахрхо буданд,

Вале омад ба гӯши ман садои рӯдхои ту.

Ба вақти бозгаштан чун расидам бар худудат ман, Зи сар то по шудам мафтуну шайдои намудат ман.

Нишастам дар замини ту, паридам дар хавои ту, Ба овози дурудат ман, ба оханги сурудат ман.

Агарчи борхо афтодам аз ёру диёрам дур,

Ба сайёхй маро карданд гарчи дӯстон машхур, Вале ман дар хама чо, дар хама кунчу канори дахр Хамеша бо Ватан будам, хамеша бо Ватан масрур.

\footnotetext{
${ }^{3}$ The word uoup in this sentence refers to Tursunzoda.
} 


\section{VOCABULARY}

Ба коми марг кашидан (v.) - to die, to expire

Бахр (n.) - sea

Вабо (n.) - cholera

Вогузор шудан (v.) - to pass, to transmit

Гузар (n.) - quarter, ward, neighborhood

Гузари Чармгарон - tanners' quarter

Дар (n.) - door

Дорулмуаллимини (n.) - teacher training institute

Дуруд (n.) - greeting

Интернат (n.) - boarding school

Иттифоқи нависандагон (n.) - Union of Writers

Корхои эчุдй - creative works

Кӯй (n.) - street, quarter

Лаёқатманд (adj.) - gifted

Мавқеъ (n.) - position; place, location

Мавч् (n.) - wave

Мадраса (n.) - madrasah, religious school

Мазхака (n.) - joke; comedy

Macpyp (adj.) - joyful, delighted

Мафтун (adj.) - fascinated, charmed, enchanted

Махрум мондан - lose, be deprived (of)

Маъмурияти (n.) - administration
Маърифатшиносӣ (n.) - Epistemology

Мехрубон (adj.) - kind

Минтақа (n.) - area, region

Мусоидат кардан (v.) - to promote, taking initiative

Навзод (adj.) - newborn

Навозиш (n.) - pampering, coddling, caress, kindness

Намуд (n.) - appearance, view

Пeca (n., Russian loanword) - play

Такмил додан (v.) - to improve

Тарбия (n.) - upbringing, education, training

Театри мусиқию мазхака - theater for musical comedy

Толибилм (n.) - pupil

Толибилм (n.) - student

Тӯфон (n.) - storm

Уқёнус (n.) - ocean

Фаъолият бурдан (v.) - to work

Форам (adj.) - pleasant, pleasing, genial

Худуд (n.) - boundary, limit, border

Хунарманд (n.) - artist

Чармгар (n.) - tanner, a person whose work is tanning hides

Чุахонбинй (n.) - world view, outlook

Шайдо (adj.) - fascinated, charmed, infatuated

Шоир (n.) - poet 


\section{EXERCISES}

Машқи 1: Чавоби дурустро интихоб намоед. (Choose the correct answer.)

1. Шоири машхури Точикистон Мирзо Турсунзода дар кадом сол таваллуд шудааст?
a) 1911
b) 1920
c) 1977

2. Дар сини 9 солаги Мирзо Турсунзода дар тарбияи кй монд?
a) модар
b) падар
c) мактаб

3. Дар соли 1927 Мирзо Турсунзода тахсили худро дар кучо давом дод?
a) дар мадрасаи Бухоро
b) дар интернат
c) дар Дорулмуаллимини Тошканд

4. Ба фикри шумо шоир дар солхои охири хаёташ кадом вазифаро пеш мебурд?
a) устоди калони Донишгохи Миллй
b) раиси Иттифиоқи Нависандагони Точикистон
c) рохбари ширкатхои тичоратй

5. Ба фикри шумо шоир бо кадом сабаб соли 1933 Душанберо тарк карда дар Хучанд истиқомат намуд?
a) аз сабаби вазифаи давлати доштан
b) аз сабаби бо Сабохат Низомиддиновна издивоч кардан
c) аз руйи зарурат

Машқи 2: Калимахои хаммаъноро мувофиқат намоед. (Match the synonyms in the following table.)

\begin{tabular}{|l|l|}
\hline 1. Толибилм & $\circ$ Дилписанд \\
2. Маъмурият & $\circ$ хонанда \\
3. Форам & $\circ$ шоиста \\
4. Худуд & $\circ$ мудирият \\
5. Лаёқатманд & $\circ$ атроф \\
\hline
\end{tabular}


Машқи 3: Барои чумлахои дуруст харфи [Д], ва барои чумлахои нодуруст харфи [Н] - ро интихоб намоед? (Choose [Д] for the true statements and $[\mathrm{H}]$ for the false.)

1. Шоири муосири точик Мирзо Турсунзода дар шахри Душанбе ба дунё омадааст. [Д/Н]

2. Мирзо Турсунзода дар синни шонздах содагй аз модар чудо шуд. [Д/H]

3. Устод Айни дар такмили чахонбинй ва маърифатшиносии Мирзо таъсири бузург расонидааст. [Д/Н]

4. То соли 1924 дар Қаратоғ мактабхо ба усули нави таълим фаъолият мекарданд ва пеш аз М. Турсунзода хонандагони зиёде ин гуна мактабхоро хатм намуда буданд. [Д/Н]

5. М.Турсунзода аз соли 1946 то охири хайёташ хамчун раиси Иттифоқи нависандагони Точикистон фаъоливят намудааст. [Д/H]

Машқи 4: Чумлахоро мувофиқи маъно/замон бо истифода аз калимахои дар қавс оварда шуда ба охир расонед. (Complete the following sentences with the appropriate word/form of the verbs in parenthesis.)

1. Мирзо Турсунзода дар дехаи Қаратоғ соли 1911 . (ичро кардан/таваллуд шудан)

2. Дар солхои 1920-уми асри 20 дар водии Хисор шадиде пахн шуд, ки модари Мирзоро ба коми марг кашид. (беморй/хушксолй)

3. Дар айёми тахсил дар шахри Тошканд Мирзо Турсунзода бо устод Айнй . (шинос шудан/шикастан)

4. Мирзо Турсунзода дар шахри Хучанд дар айёми фаъолияти корияш бо Сабохат Низомиддинова бунёд мекунад. (оила/эчодй)

5. Мирзо Турсунзода дар соли 1946 раиси Иттифоқи нависандагони Точикистон . (аз даст додан/ интихоб шудан) 


\section{CHAPTER 6: TAJIK CIVIL WAR}

\section{Чанги Шахрвандии Точикистон}

Воқеахои фочиавии ${ }^{1}$ аввали солхои 90 -уми Чумхурй хамчун сахифаи сиёх ба таърихи халқи точик дохил гардидаанд. Ин воқеахо дар матбуоти даврй, китобу мақолахо бо чунин номхо "чанги бародаркуш," “чанги шахрвандии," "чанги минтақавй” ва ғайра баён ёфтаанд².

Чанги бавукӯъ омада сабабхои объективй ва субъективии худро дошт. Аввалан, дар рафти бозсозй чй дар миқёси Иттифоқ ва чй Чумхурии Точикистон мушкилихои иқтисодй ба амал омаданд. Аз кор мондани баъзе корхонахо, ба фурушш нарафтани махсулот, сари вақт нагирифтани мохона, зиёд шудани микдори бекорон торафт норозигиро бештар мекард. Сониян, дар ибтидои солхои 90-ум норозигии ичтимой шиддат гирифта, мардуми баъзе нохияхо ба хуррок, либос, пойафзол муххточй мекашиданд. Точикистон аз чихати афзоиши ахолй дар чои аввал меистод, вале ба таъминот ва хизматрасонии маишй, тиббй алалхусус нисбат ба кӯдакон дар дехот, начандон диққат дода мешуд³. Сол аз сол фавти кӯдакон меафзуд.

Нохамвории тараққиёт, сууистеъмоли ${ }^{4}$ вазифа ва вайрон кардани қонуният дар махалхо, инкишофи ришвахӯрй, дуздй низ норозигии халқро бештар мекард. Хамин тавр, заминахои воқеахои фочиавй пухта расида ба сар задани он як шӯъла лозим буд.

Дар раванди демократикунонии чамъият, ошкорбаёнй, хизбхои нави сиёсй, аз чумла хизби демократ ва хизби нахзати ислом ба майдон омаданд, ки аз норозигихои бавукӯъ омада истифода бурда, мехостанд барномахои худро татбиқ намоянд. Чои махфй нест, ки ба ин кор як гурӯх қуввахои хоричй хам даст зада, ба сар задан ва аланга гирифтани чанги дохилй хиссаи худро гузоштанд.

Баъд аз воқеахои мохи феврали соли 1990 хизби нахзати ислом аз пинхонкорй баромада, охиста-охиста дар якчоягй бо дигар хизбу

\footnotetext{
${ }^{1}$ Фочиавй is an adjective derived from the noun Фочиа. When it is used in an izâfat construction, the letter " $\bar{и}$ " changes into " $и$ " because " $\bar{и} "$ is used in only a word-final position. For a detailed discussion of $i z \bar{a} f a t$, see John R. Perry, A Tajik Persian Reference Grammar (Leiden, Boston: Brill Academic Publishers: 2005), 71-83 and for a very brief reference see Shinji Ido, Tajik (Muenchen : Lincom Europa, 2005), 12. 26-27

${ }^{2}$ баён ёфтааст (has been described) is the passive form of баён кардааст. In order to make passive of some of the compound verbs with кардан, кардан is replaced by ёфтан. . For a detailed discussion of passive, see John R. Perry, A Tajik Persian Reference Grammar, 247-76 and for a very brief reference see Shinji Ido, Tajik, 12. 67-68.

${ }^{3}$ Начандон диққат дода мешуд (not much attention used to be/were (being) paid) is a passive form [Past participle + appropriate tense of $ш y \partial a \mu]$.

${ }^{4} C \bar{y}$, also written as $c y$ (as in Parvona Jamshedov, Tajik-English Dictionary second edition, Dushanbe, 2008), means bad, ill, evil. It is used as a prefix to supply negative meaning as in суистеъмол (or суистеъмол) [prefix су + истеъмол (use)] 'misuse' or суитафохум [prefix су $(u)+$ тафохум (understanding)] 'misunderstanding'.
} 
созмонхо ва харакатхо байни шахрвандон кори сиёсиро пеш гирифтанд. Онхо аз 26 март то 17 майи соли 1992 митинги фавкулодаро дар майдони Шахидон ташкил намуданд, ки вай дар зери шиорхои сиёсии зидди хукумат ва дастгирии ислом мегузашт. Муборизон бо митинг қаноат накарда, аъзоёни хукумат ва парламентро гаравгон гирифтанд. Дар чавоб мохи майи соли 1992 дар майдони Озодй митинг барпо гардид, ки вай мақомоти хокимияти конститутсиониро дастгирй намуда, Раиси Чумхуриро химоя мекард. Дар натича дар рафти ин муқовимати аввалин кушторхо ба амал омаданд.

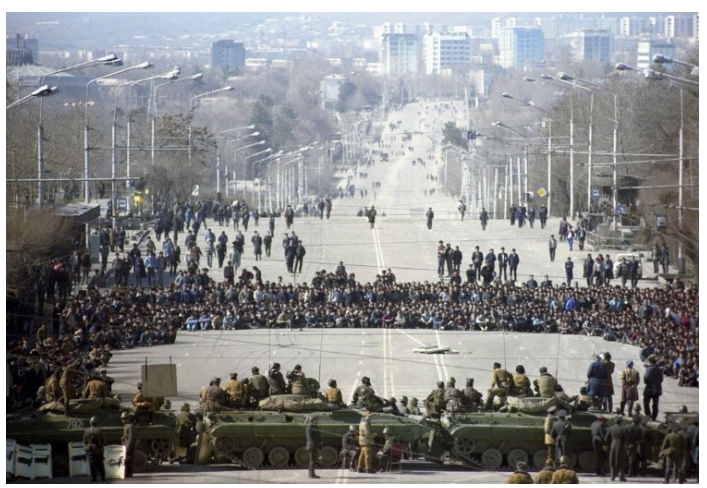

Dushanbe riots, February $1990^{5}$

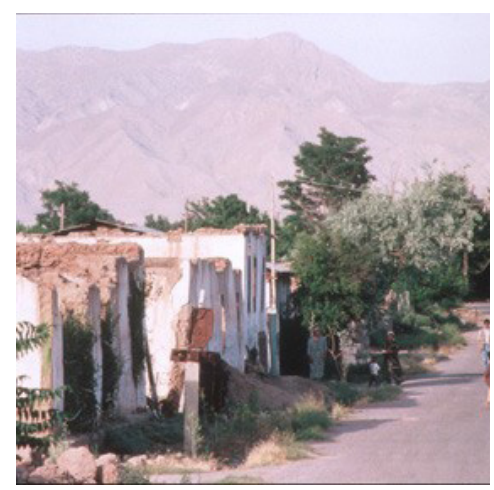

A house destroyed during civil war in Khatlon Province. ${ }^{6}$

Бо мақсади хотима додани ин фочиахо хукумати эътилофй (коалисионй) ташкил ёфт. Вале ин хукумат аз уухдаи хомӯш кардани воқеахои сиёсй баромада натавонист ${ }^{7}$ ва мохи июни соли 1992 амалиёти чангй дар вилояти Курғғонтеппа сар шуд. Хамин тавр, оташи чанги дохили ё худ шахрвандй аланга зад ва байни шахрвандон бо ном қаротегинхо ва кӯлобихо задухуррд ба амал омада, одамони бегунох кушта шуданд. Хазорон шахрвандон ба Афғонистон, Ӯзбекистон, Туркманистон, Россия ва дигар кишвархои хорич фирор карданд. Чанг ба чомеа хам аз чихати маънавй ва хам аз чихати моддй зарар расонда, одамони зиёде ба халокат расиданд.

(Text taken from: Таърихи Халқци Точчик (Grades 9 and 11 History Textbook, Tajikistan) by Р. Набиева, Ф.Зикриёев)

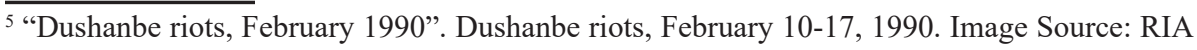
Novosti archive, http://visualrian.ru/ru/site/gallery/\#699865

${ }^{6}$ A house destroyed during the 1992 civil war in Khatlon Province, Tajikistan. Image Source: UNHCR

${ }^{7}$ The modal verb тавонистан is also used with subjunctive. For example, aз $\bar{y}$ дал хомуй кардани воқееахои сиёси баромада натавонист can also be written as натавонист аз удхудаи хомӯш кардани воқуеахуои сиёсй барояд.
} 


\section{VOCABULARY}

Аз кор мондан - stop working

аз уухдаи (коре) баромадан - to

fulfill the task of, to be able (to do), to succeed (in a work)

Аланга - flame

Афзоиши ахолй - population growth

Ахолй (n.) - population

Бекор (n.) - unemployed

Бозсозй (v.) - revival, restoration

Вайрон кардан (v.) - to break, to destroy

Воқеа (n.) - event

Дар миқёси - on the scale of

Дастгирй - help, assistance

Демократикунони - democratization

Диққат - attention

Иқтисодй (adj.) - economic

Ичтимой (adj.) - public, social

Кўдакон (n.) - children

Матбуот (n.) - press

Минтақа (n.) - area, region

Мӯхточй кашиданд - to be in need of smth

Мушкили (n.) - difficulty, challenge

Начандон - not enough

Норозигй - dissatisfaction,

disagreement
Пойафзол/Поафзол (n.) - footwear

Сабаб (n.) - reason

Сӯъистеъмол кардан (v.) - to abuse

Тараққиёт (n.) - progress, development

Таъминот (n.) - supply

Торафт (adv.) - Steadily, continuously

Фирор (n.) - run away, escape

Фочиавӣ (adj.) - tragic

Халқ (n.) - people

Хизматрасони (n.) - service

Хизби демократй - democratic party

Хизби нахзати ислом - Islamic revival party

Хизбхои нави сиёсй - new political parties

хукумати эътилофй - coalition government

Чุамъият (n.) - society

Чанг (n.) - war

Чанги бародаркушй - the Civil War

Шахрвандй (adj. ) - civil

Шиддат (n.) - power, force, intensity

Шиор (n.) - motto, slogan

Шӯъла (n.) - light, flame 


\section{EXERCISES}

Машқи 1: Чавоби дурустро интихоб намоед. (Choose the correct answer.)

1. Дар ин мақола сухан дар бораи кадом чанг меравад?
a) чанги бо Иттифоқи Шуравй
b) чанги шахрвандй
c) чанги чахонй

2. Дар ин мақола кадом намуди мушкилии иқтисодй зикр нашудааст?
a) зиёд шудани микдори бекорон
b) дар вақташ нагирифтани мохона
c) бекурб шудани асъори миллй

3. Хадафхои асосӣ иштирокчиёни митинги майдони Шахидон чихо буданд?
a) дастгирии принсипхои ислом ва зидди хукумат
b) озодии сухан
c) дастгирии сиёсати хукумат

4. Тарафдорони раиси Чумхур дар кадом майдон чамъ омаданд?
а) дар майдони Шахидон
b) дар майдони Озодй
c) дар вилояти Куррғонтеппа

5. Барои чи хазорон шахрвандон ба Афғонистон, Уузбекистон, Туркманистон, Россия ва дигар кишвархо мухочират намуданд?
a) барои вусъат додани тичорат
b) барои пайдо намудани кор
c) барои фирор ба чойхои амну сулх

Машқи 2: Калимахои хаммаъноро мувофиқат намоед. (Match the synonyms in the following table.)

\begin{tabular}{|l|l|}
\hline 1. Халқ & $\circ$ пешрафт \\
2. Чанг & $\circ$ \\
3. Муммак \\
4. Дастгирй & $\circ$ мардум \\
5. Тараққиёт & $\circ$ монеъа \\
\hline
\end{tabular}


Машқи 3: Барои чумлахои дуруст харфи [Д], ва барои чумлахои нодуруст харфи [Н] - ро интихоб намоед? (Choose [Д] for the true statements and $[\mathrm{H}]$ for the false.)

1. Мохи майи соли 1992 дар майдони Озодй митинг бар зидди хукумат барпо гардид. [Д/Н]

2. Хазорон сокинон ба Туркманистон, Ўзбекистон, Афғонистон, Россия ва дигар кишвархои хорич мухочират карданд. [Д/Н]

3. Мухолифин бо гирдихамоиву рохпаймоихо қаноатманд шуда, бо кормандони хукумат ва парлумон хамкориро пурзур ва наздиктар намуданд. [Д/Н]

4. Сараввал дар рафти бозсозй танхо дар ЧุТ мушкилихои иқтисодй ба амал омад. [Д/Н]

5. Чанги Шахрвандй дар матбуот, китобу мақолахо бо номхои “чанги бародаркуш”, “чанги минтақавй” низ навишта шудааст. [Д/Н]

Машқи 4: Чумлахоро мувофиқи маъно/замон бо истифода аз калимахои дар қавс оварда шуда ба охир расонед. (Complete the following sentences with the appropriate word/form of the verbs in parenthesis.)

1. Сол аз сол фавти кўдакон . (кам кардан/ афзудан)

2. Дар ибтидои солхои 90-ум, мардум ба хўрок, либос ва пойафзол рӯбарӯ шуда буданд. (камбуд/ минтақа)

3. Чанги шахрвандии Точикистон сабабхои объективй ва субъективии дошт. (худро/ фирор)

4. Гуфта мешавадки яқе аз асосии чанги шахрвандй дар Точикистон дахолати хоричй буд. (сабабхои/шахрвандон)

5 . митинги майдони Озодй мақомоти хокимияти конститутсиониро дастгирй намуда, Раиси Чумхуриро химоя мекарданд. (иштирокчиён/коргарони) 


\section{CHAPTER 7: MILITARY COLLEGE}

\section{Донишкадаи харбй}

Донишкадаи харбии Вазорати мудофиа зодаи Истиқлолияти Точикистон аст. Дар соли таъсисёбиаш Коллечи олии харбии фармондехймухандисй номгузорй шуда буд. Аввалин курсантону сарбозон бошанд, 23 феврали соли 1993, дар руузи таъсисёбии Қуввахои Мусаллахи Чумхурии Точикистон савганди харбиро ёд намуда, дар намоиши ботантанаи харбй иштирок карда буданд.-

Донишкадаи харбии Вазорати мудофиа фаъолияташро мутобиқи талаботи эхтиёчи Куввахои Мусаллахи Чумхурии Точикистон пеш мебарад. Хайати шахсии донишкада тулли фаъолияташ дар байни қисмхои низомй ва муассисахои таълимии Вазорати мудофиа дар мусобиқахои харбй чойхои намоёнро ишғол кардаанд. Аз рӯи нақшаи тасдиқшудаи ректори донишкада бошад, дар байни хайати шахсии курсантону сарбозон пайваста мусобиқахои варзишй гузаронида мешаванд. Холо дар донишкада хобгохи чорошёна, ду бинои таълимй, толор ва майдони варзишй, хаммом, дармонгохи тиббй, мачлисгох, китобхона, ду толори лексионй, осорхонаи “Шарафи чангй”, парки автомобилй, чойи тирпарронй, китобхонаи электронй, синфхонахои компютерй ва лингофонй, майдончаи тактикй, оркестри мусиқачиёни харбй, ошхона дар хизмати афсарон, прапоршикхо, курсантхо ва сарбозон мебошанд.

Инчунин дар донишкада хонахои фароғатй - иттилоотй мучаххаз бо васоити иттилоърасонй мавчуданд, ки курсантхо ва сарбозон дар вақти муайяншуда метавонанд аз воқеоти рӯз хабардор гарданд. Дар донишкада барои аз худ намудани забонхои хоричй ахамияти махсус дода мешавад. Донишчуё̈н ба омӯзиши забонхои русй, англисй, фаронсавй, олмонй чалб гардидаанд. Аз суухбат бо сардории шўъбаи таълим Саъдй Гулов маълум гардид, ки ду маротиба аз Афғонистон ва чор маротиба аз Британияи Кабир сарбозону афсарон омада, дар донишкада аз курсхои кӯтохмуддати омӯзиши забони точикй гузаштаанд. Курсантону сарбозоне, ки курсхои омӯзишии забонхои хоричиро дар донишкада гузаштаанд, имкони дар хорича тахсил карданро доранд. Ва чандин нафари дигар низ рафта дар хорича тахсил кардаву баргаштанд.

Таълиму касбомуззй дар донишкада тавре ба рох монда шудааст, ки аз нигохи тахассусй хатмкардахо метавонанд, дар дигар сохахои хочагии халқ низ фаъолият намоянд. Махз афсарони хақиқии Ватан дар хамин мактаби мардонагй ташаккул меёбанду ба воя мерасанд, мегўяд сардори қисми тарбия, подполковник Р. Абдурахмонов.

(Text taken from the newspaper “Омуузгор”, 18.02.11) 


\section{VOCABULARY}

Аълочии маориф (n.) - an awardee of honor in the field of education in Tajikistan

бинои таълимй (n.) - building for studies

Ботантана (adj., adv.) - solemn, solemnly

Восита (n.) |Pl. васоит| - instrument, facility; intermediary

Воя (n.) - adulthood

Гуманитарӣ (adj.) - humanitarian [фанхои гуманитарй 'humanities']

Дақиқ (adj.) - exact

дармонгохи тиббй (n.) - hospital

Донишкадаи харбй (n.) - Military college

Истиклолият (n.) - independence

Ихтисос (n.) - specialty

китобхона (n.) - library

китобхонаи электронй - library with computers

китобхонаи электронй (n.) electronic library

Курсант (n.) - student

Кӯтохмуддат (adj.) - short-term

Қуввахои Мусаллах - armed forces

Куввахои Мусаллахи Чумхурии

Точикистон (n.) - Armed Forces

майдони варзиши (n.) - sports ground

майдони тактикй (n.) - the training ground for tactics

мачлисгох (n.) - meeting hall
Мудофиа (n.) - defense

Мусиқачиён (n.) - musicians

Мусобиқахои варзишй (adj.) - sports competitions

Намоиш (n.) - show, performance

осорхона (n.) - museum

ошхона (n.) - dining- room

парки автомобилй (n.) - car park

Подполковник (n.) - lieutenant colonel

Савганд (n.) - oath

Сарбоз (n.) - soldier

синфхои компютерй (n.) - computer classrooms

Таълим додан (v.) - to train, to teach

Таъсис ёфтан (v.) - to be created

толор (n.) - hall

толори лексионй - lecture hall

Хатмкунанда (n.) - a graduator

хобгох (n) - dormitory

Хайат (n.) - body, staff, board

хаммом (n.) - bathroom

Харб (n.) - war

Чุамъиятӣ (adj.) - social

Чойи тирпаронӣ (n.) - shooting range

чорошёна (adj.) - four-storied

building

Шахсӣ (adj.) - personal 


\section{EXERCISES}

Машқи 1: Чавоби дурустро интихоб намоед. (Choose the correct answer.)

1. Дар соли аввали фаъолияташ Донишкадаи харбии Вазорати мудофиа чй гуна коллечи олй номгузорй шуда буд?
a) харбй умумикушунй
b) харбй-хавонавардй
c) харбии фармондехй-мухандисй

2. Донишкадаи харбии Вазорати мудофиа фаъолияташро мутобиқи талаботи эхтиёчи кадом яке аз инхо пеш мебарад?
a) Кумитаи далатии амнияти миллии Чумхурии Точикистон
b) Куввахои Мусаллахи Чумхурии Точикистон
c) Вазорати корхои дохилии Чумхурии Точикистон

3. Дар донишкада чй гуна мусобиқахо гузаронида мешаванд?
a) харбй
b) варзишй
c) мусиқй

4. Донишчуеён бо омӯзиши кадом забонхо машғул хастанд?
a) русй, англисй, фаронсавй, олмонй
b) русй, англисй, чинй, олмонй
c) русй, англисй, испанй, олмонй

5. Аз кадом яке аз ин давлатхо сарбозону афсарон бо омӯзиши забони точикй омадаанд?
a) Олмон
b) Британияи Кабир
c) Иёлоти Муттахидаи Амрико

Машқи 2: Калимахои хаммаъноро мувофиқат намоед. (Match the synonyms in the following table.)

\begin{tabular}{|l|l|}
\hline 1. Мудофиа & $\circ$ Навозандагон \\
2. Савганд & $\circ$ Мухориба \\
3. Харб & $\circ$ Қасам \\
4. Савганд & $\circ$ Дифо \\
5. Мусиқачиён & $\circ$ қасам \\
\hline
\end{tabular}


Машқи 3: Барои чумлахои дуруст харфи [Д], ва барои чумлахои нодуруст харфи $[\mathrm{H}]$ - ро интихоб намоед? (Choose [Д] for the true statements and $[\mathrm{H}]$ for the false.)

1. Донишкадаи харбй ду бинои таълимй ва хобгохи чорошёна дорад. [Д/Н]

2. Хайати шахсии донишкада дар мусобиқахои харбй фаъолияти хуб нишон надода, чойхои намоёнро низ ишғол карда наметавонанд. [Д/Н]

3. Донишчуё̈ни ин муассисаи таълимй забонхои хоричиро меомӯзанд. [Д/Н]

4. Курсантхо ва сарбозон метавонанд дар хорича тахсили худро давом диханд. [Д/Н]

5. Мутаасифона имрӯз донишкада оркестри мусиқачиёни харбии худро надорад. [Д/Н]

Машқи 4: Чумлахоро мувофиқи маъно/замон бо истифода аз калимахои дар қавс оварда шуда ба охир расонед. (Complete the following sentences with the appropriate word/form of the verbs in parenthesis.)

1. Аввалин курсантону сарбозони донишкада, 23 феврали соли 1993, дар рӯзи Қуввахои Мусаллахи Чумхурии Точикистон савганди харбиро ёд намуданд. (оғозёбй/анчомёбй).

2. Дар Донишкадаи харбии Вазорати мудофиа барои омӯхтани ахамияти махсус дода мешавад. (забони модарй/ забонхои хоричй)

3. Таълиму касбомӯзй дар Донишкадаи харбии Вазорати мудофиа тавре тахрезй шудааст, ки аз нигохи тахассусй хатмкардахо , дар сохахои гуногуни хочагии халқ низ фаъолият намоянд. (месупоранд/метавонанд)

4. Донишкадаи харбии Вазорати мудофиа фаъолияташро мутобиқи талаботи эхтиёчи Қуввахои Мусаллахи Чумхурии Точикистон . (ба рох мондан/аз байн бурдан)

5. Дар донишкада хамаи шароитхои барои баланд бардоштани сифати таълим . (назар кардан/мавчуд будан) 


\title{
CHAPTER 8: RELIGIOUS EDUCATION IN TODAY'S TAJIKISTAN
}

\author{
Маорифи динй дар Точикистони имрӯза
}

Яке аз чанбахои ба созиши исломию дунявй даст ёфтан халлу фасли мушкилоти динист. Ба ин доира масъалахои зиёде, аз чумла маълумоти ибтидоии динии кӯдакон ва наврасон, маърифати динии эътиқодмандони калонсол, таълиму тарбияи рўхониён ва омўзгорон, маълумоти олии илохиётшиносй, сомондихии тадқиқоти илмй дар бахши илохиётшиносй, таъбу нашри адабиёти таълимии динй ва дигар васоити таълимй (мавод ва лавозимоти видеой, аудиой, роёнай) ва ғайра дохил мешавад. Мушкилии асосй дар халли масоили фавқуззикр иборат аст аз адами муносибатхои якхела байни арбобони динию намояндагони давлат ва дар мачмӯъ байни ахли чомеаи Точикистон нисбати он, ки маърифати динй чй гуна бояд бошад, кй онро амалй созад, кй маблағгузорй намояд ва давлат дар маърифатнокшавии динии шахрвандони Чумхурии Точикистон чй нақш бояд бибозад. То хол на фақат масъалаи динй, балки инчунин масъалаи тарбияи динй халли хешро наёфтааст.

Қонунгузории Чумхурии Точикистон низоми давлатии маорифро аз дин чудо нишон медихад. Ба шахрвандон хуқуқи фарогирии дониши динй ва дар макотиби динй хосил кардани маърифати динй дода шудааст. Омӯхтани таълимоти динй барои атфол танхо хангоми ба синни хафт расидан ва бо розигии хаттии волидайн, дар холи шонздахсолагй бошад, бо ризоияти онхо ва берун аз соатхои тадриси мактаби маъмулй ичозат аст.

Тачриба нишон медихад, ки қонунгузорй усулу қавоиди умумиро муайн карда, айни замон на хама чанбахои масоилеро, ки дар чараёни истикрор ва фаъолияти муассисахои динй падид меоянд, фаро мегирад. Ин шигифтангез хам нест, агар мӯчиботи зеринро ба назар бигирем: аввало, низоми маорифи динй дар солхои хукумати Шурравй тахриб ёфта, амалан танхо дар шакли дабистонхои ғайрирасмии динй - хучрахо боқй монда буд; дуввум, замони муосир навсозии низоми маориф, аз чумла маорифи диниро тақозо дорад. Ва ин навсозй масоилу суолхои афзунеро пешорӯи мо мегузорад, ки ба онхо алхол на давлат ва на ричоли динй чавоби қаноатбахш додан наметавонанд.

Дар муддати омодасозии ин гузориш мо перомуни он масъалахо ба афкору ақоиди мухталиф вохуррдем. Мавқеи пурсидашудагонро ба се бахш тақсим кардан мумкин:

1. Азбаски Қонуни асосии Чумхурии Точикистон чудоии динро аз давлат таъкид месозад ва динпазириро кори шахсии шахрвандон эълон менамояд, мактаб аз дин чудост ва маорифу фарханг хусусияти дунявй доранд. Таълиму тарбияи динй бояд вазифаи муассисахои диниву хайриявй бошад. Давлат ба чараёни тадрис набояд кордор шавад. Фанхое, ки дар муассисахои динй омӯхта 
мешаванд, бояд ба анъанахои миллй созгор бошанд. Чунин ақидаро қисми зиёди маъмурони давлатй ва мачмӯан қисми зиёди шахрвандони дорои маълумоти олй чонибдор хастанд.

2. Бештар аз 90 дарсади ахолии Точикистон мусулмононанд, бад-ин чихат ислом бояд ба номгууи дарсхои омӯзишии мактабхо шомил ва назарияхои дахриёнаву дарвинизм аз он хорич карда шаванд.

3. Дар мактаб кӯдаконро дуову намоз омӯзонидан бемаънигист, барои ин чойхои мувофиқтаре чун масчиду мадрасахо мавчуданд. Вале давлат бояд аз лихози моддй муассисахои таълимии диниро дастгирй созад ва назорат намояд, ки муллохо атфолро чй меомӯзонанд ва чй гуна. ${ }^{1}$

(Text taken from Саодат Олимова, “Маорифи динй дар Точикистони имрӯза," in Истикрори Боварй Миёни Исломиён ва Дунявигароён Тачрибаи Точчкон, (Душанбе-2004), 330-332)

\section{VOCABULARY}

Нашр (n) - publication

Арбоб (n) - prominent person, notable

Атфол (n) - children

Балки (conj) - but, however

Бемаънигй (n) - nonsense

Васоити таълими, мавод (n)- teaching /learning materials

Ғайрирасмӣ (adj) - informal

Дабистон (n) - school

Дастгирй (n) - help, assistance

Дин (n)-religion

Дорой (n) - richness, property

Илохиётшиносй (n)-theology, divinity

Калонсол (adj) - elderly
Маблағгузорй (n) - financing

Мадраса (n) - madrasa, religious educational center

Маориф (n) - education

Маориф (n.) - education

Масчид(n) - mosque

Маълумоти олй (n) - Higher

Education

Моддй (adj)-material

Myaccuca (n) - institute, institution

Мулло (n) - cleric

Мушкилй (adj) - difficulty

Низом (n) - system, structure

Рӯхониён (n) - clergymen

\footnotetext{
${ }^{1}$ меомузонанд is in causative form. The causative form is formed by adding -ондан or онидан to the present stem of a verb (usually an intransitive). For eхample, хуррдан 'to eat' changes into хуррондан (present stem хурр + -ондан) 'to feed' in the causative form.
} 
Созиш (n.) - adaptation, agreement, reconciliation

Тадқиқот (n) - research

Тадрис (n) - teaching

Тачриба (n) - practice, experience

Фақат (adv) - only

Фаро гирафтан (v) - to learn, to embrace
Халлу фасл (n.) - settlement, disposition

Хорич карда шавад(n) - expel, remove

Хукумати Шууравй - Soviet

government

Хучра(n) - room

Шахрвандон (n)-citizen

Эътиқодманд (adj) - faithful

\section{EXERCISES}

Машқи 1: Чавоби дурустро интихоб намоед. (Choose the correct answer.)

1. Аз рўйи қонунгузории Чумхурии Точикистон

a) маориф аз дин алохида аст

b) маориф ва дин вобастаги доранд

c) дин нисбат ба маориф афзалият дорад

2. Дар солхои Хукумати Шурравй низоми маърифати динй чи тавр буд?
a) расмй
b) ғайрирасмй
c) пахншуда

3. Кй дар Чумхурии Точикистон таълиму тарбияи диниро ба ухда мегирад?
a) давлат
b) муассисахои динй
c) идорахои фархангй

4. Оё дар муассисахои давлатй омӯзонидани дуову намоз мумкин аст?
a) танхо бо хохиши волидайн
b) ичозат дода мешавад
c) ичозад дода намешавад

5. Барои муайян намудани вазъи масъалаи маорифи динй чи корхо гузаронида шуд?
a) конференция баргузор гашт
b) пурсиши ахолй гузаронида шуд
c) қонуни қабул карда шуд 
Машқи 2: Калимахои хаммаъноро мувофиқат намоед. (Match the synonyms in the following table.)

\begin{tabular}{|l|l|}
\hline 1. Тадқиқот & $\circ$ Танхо \\
2. Мулло & $\circ$ ёд гирафтан \\
3. Фаро гирафтан & $\circ \quad$ кумак \\
4. дастгирй & $\circ \quad$ пажӯхиш \\
5. Фақат & $\circ$ руххонй \\
\hline
\end{tabular}

Машқи 3: Барои чумлахои дуруст харфи [Д], ва барои чумлахои нодуруст харфи [Н] - ро интихоб намоед? (Choose [Д] for the true statements and $[\mathrm{H}]$ for the false.)

1. Омўхтани таълимоти динй барои атроф аз синфи 7 сар карда ва бо розигии хаттии волидайн ичозат дода мешавад. [Д/Н]

2. Дар солхои Хукумати Шўравй низоми маорифи динй амалан танхо дар шакли дабистонхои ғайрирасмй боқй монда буд. $[Д / \mathrm{H}]$

3. Бештар аз 90 дарсади ахолии Точикистон фикр мекунанд ки Таъмини тарбияи динй бояд вазифаи давлат бошад. [Д/Н]

4. Фанхое, ки дар муассисахои динй омўхта мешавад, бояд ба анъанахои миллй созгор набошад. [Д/Н]

5. Қонуни асосии Чумхурии Точикистон динпазириро кори шахсии шахрвандон эълон менамояд. [Д/Н]

Машқи 4: Чумлахоро мувофиқи маъно/замон бо истифода аз калимахои дар қавс оварда шуда ба охир расонед. (Complete the following sentences with the appropriate word/form of the verbs in parenthesis.)

1. Дар масчид ва мадрасахо дуову намоз (омўзонида шудан/дидан)

2. Дар Точикистон давлат муассисахои таълимии диниро мекунад. (назорат/ беэътиной) 
3. Дар дарачаи дастгирии амалиёти давлат нисбат ба дин миёни гурўххои синну соли гуногун тавофут (мондан/мушохида шудан)

4. Дар дурнамои Точикистон ба дин мақому манзолати саровор .(дода шуд/хобидан)

5. Омўхтани барои атфол берун аз соатхои тадриси мактаби маъмулй ичозат дода шудааст. (таълимоти динй/техникй) 


\section{CHAPTER 9: ENTREPRENEURSHIP: THE DRIVING FORCE OF MARKET ECONOMY}

\section{Сохибкорй фишанги иқтисоди бозорист}

Сохибкорй яке аз самтхои мухим ва фишанги пешбарандаи иқтисоди бозорй мебошад. Чй хеле ки тачрибаи чахонй нишон медихад, инкишофи сохибкорй ба халли як қатор масъалахои илмию техникй ва ичтимоиву иқтисодй мусоидат мекунад.

Фаъолияти сохибкорй хамеша эхтиёч ба ёрй ва дастгирии давлат дорад. Хукумат шароити мусоидро таъмин менамояд, ки бе ин сохибкорон наметавонанд самаранок кор карда, фоида ба даст оваранд. Аз ин ру, дастгирии давлатии сохибкорй яке аз самтхои афзалиятноки сиёсати Хукумати кишвар аст. Дар ин замина як қадами эътимодбахш ин қабули Консепсияи рӯшди сохибкорй аз 3 декабри соли 2004 мебошад, ки ба дастгирии давлатии сохибкорй равона гардидааст.

Барои амалй намудани ин сиёсати хадафманд Эмомалй Рахмон, Президенти чумхурй, дар Паём ба Мачлиси Олй Хукумати мамлакат, мақомоти дахлдор аз чумла Кумитаи давлатии сармоягузорй ва идораи амволи давлатй, вазорату идорахо ва мақомоти ичроияи махаллии хокимияти давлатиро вазифадор карданд, ки барои дастгирии минбаъдаи сохибкорй, бахусус дар сохахои истехсолй ва бартараф намудани монеахои маъмуриву сунъй чорахои қатьй андешанд. Хамчунин Сарвари давлат дар Паёми худ зикр намуданд, ки дар соли сипаригашта як қатор тадбирхо барои чалби сохибкорон ва пешрафти сохибкорй амалй шудаанд. Аммо хамаи ин чорачӯихо ханӯз талаботи имрӯзаро қонеъ карда наметавонанд ва вобаста ба рушшди иқтисодиёти мамлакат рохандозии тадбирхои судмандро бояд солхои оянда низ идома дод.

Хамзамон Президенти мамлакат ба Хукумат ва сохтору мақомоти дахлдори давлатй дар мавриди бехтар намудани фазои сармоягузорй ва дастгирии сохибкорй, аз чумла ба андозаи 2,3 баробар кам намудани шумораи молхои хатман сертификатсияшаванда аз 7100 номгуй̆; чорй намудани низоми “равзанаи ягона” оид ба расмиёти содагардонидашудаи воридоту содирот; 50 дар сад кам намудани номгўи андозхо; ихтисори пурраи андоз аз фурӯши чакана; озод намудани воридоти тамоми номгуй тачхизоти технологии хозиразамон аз хамаи намудхои андоз ва пардохтхои гумрукй, супоришхои мушаххас дод.

Боиси қаноатмандист, ки бо назардошти сахми мухими сохибкорони кишвар дар раванди созандагиву бунёдкорй, рӯшди иқтисодиву ичтимоии мамлакат ва анчоми корхои хайру эхсон Президенти мамлакат ба онхо миннатдории самимй баён намуд. Ин хама аз он гувохй медихад, ки давлат ва Хукумати кишвар ба масъалаи инкишоф ва мақоми арзишманди ичтимоии сохибкорон дар раванди бозсозии кишвар таваччухи хоса зохир менамояд.

(Text taken from the newspaper Чумхурият, June 19, 2012) 


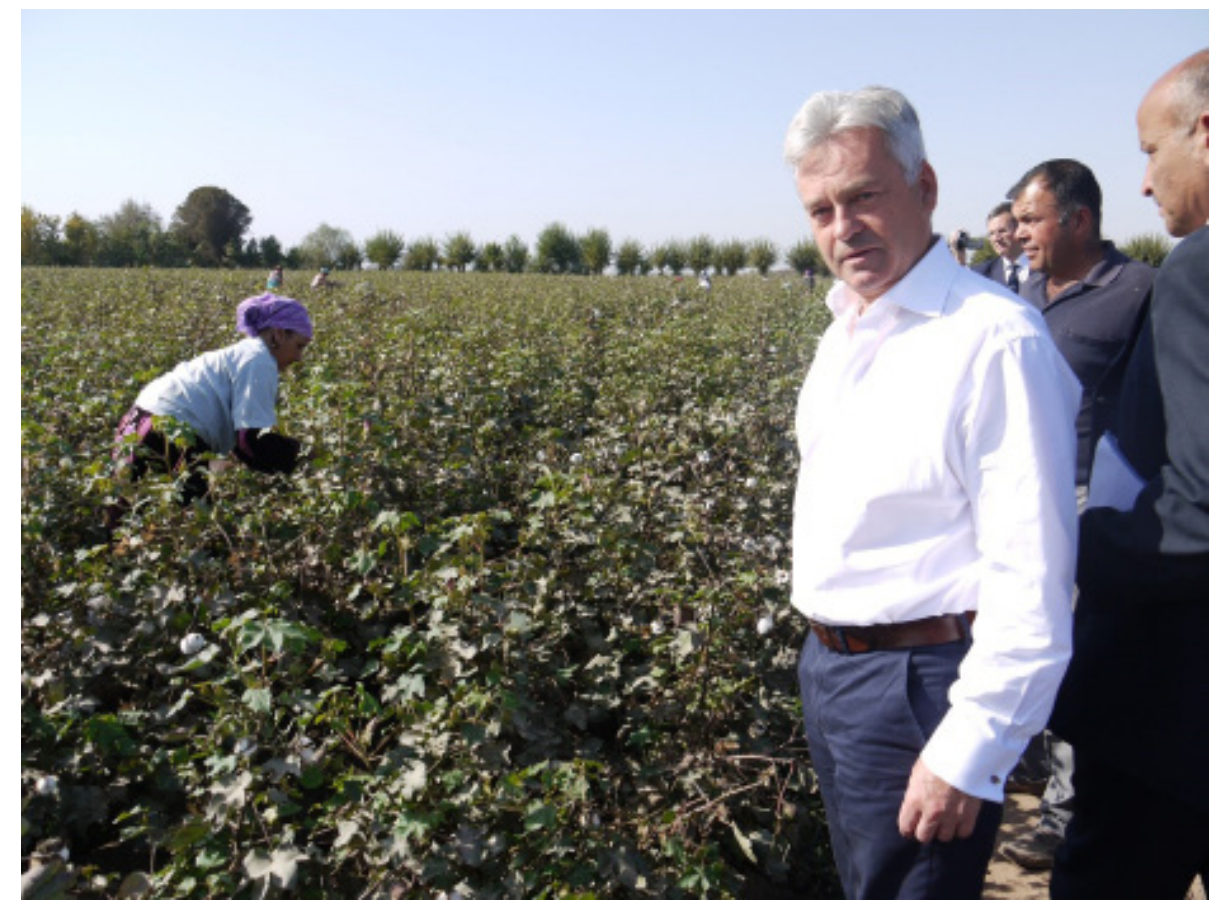

(Alan Duncan, the first UK Government Minister to visit Tajikistan, in a cotton field)

\section{VOCABULARY}

Андоз (n.) - tax

Андоза (n.) - measurement, degree

Афзалиятнок (adj.) - preeminent

Бе (prep.) - without

Воридот (n.) - import

давлат (n.) - state

Дастгирй (n.) - help, assistance

Дахлдор (adj.) - concerning, relevant

зикр намудан (v.) - to mention

идома додан (v.) - to continue

илм (n.) - science

қонеъ кардан (v.) - to satisfy мамлакат (n.) - country

Маччлиси Олй (n.) - Supreme

Assembly (parliament)

Минбаъда (adj.) - subsequent, following, further; минбаъдаи фарханг - further development of the culture

молхо (n.) - goods

Номгӯй (n.) - list, index, directory

оянда (n.) - future

Паём (n.) - message, speech

пардохт (n.) - payment

Пурра (adj., adv.) - whole, full; wholly 
рӯшди иқтисодиву ичтимой economic and social development

Самаранок (adj.) - profitable, efficacious, productive

Самт (n.) - side

санчиш (n.) - test, examination

сарвар (n.) - leader

Сармоягузорй (n.) - investment

$\operatorname{caxm~(v.)~-~share~}$

соли сипаригашта - last year

Coхтор (n.) - structure; сохтори давлатӣ - state structure

Сохибкор (n.) |P1. сохибкорон|businessman, proprietor, entrepreneur

Сохибкорй (n.) - entrepreneurship судманд (adj.) - useful супориш додан/кардан (v.) - to give a task, to assign

тадбир (n.) - measure, decision

Тачхизот (n.) - equipment

Таъмин намудан (v.) - to provide

Фазо (n). - space, atmosphere

Фаъолият (n). - activity

Фишанг (n.) - lever; cartridge

Фоида (n.) - profit

Чакана (n.) - retail

чалб (n.) - attract

Шароити мусоид - favorable conditions

Эътимодбахш (adj.) - confidencegiving, assuring

\section{EXERCISES}

\section{Машқи 1: Чавоби дурустро интихоб намоед. (Choose the correct answer.)}

1. Сохибкорй дар Точикистон аз тарафи давлат ...
a) манъ карда мешавад
b) танқид карда мешавад
с) дастгирй карда мешавад

2. Кадом хуччати давлатй дар бораи сохибкорй қабул карда шуд?

a) Консепсияи рушшди илму маориф

b) Консепсияи рушшди сохибкорй

c) Консепсияи миллй Точикистон

3. Сохибкорони кишвар бахотири корхои бунёдкоронаву хайру эхсонашон аз кй миннатдории самимй шуниданд?
a) аз рохбари кишвар
b) аз худи сохибкорон
c) аз сокинони мардуми водихои дурдаст 
4. Барои ворид намудани тачхизотхои нави хозиразамона сохибкорон чй имтиёзхо пайдо намуданд?
a) пардохтхои гумрукй барои тачхизотхои нав баланд карда шуд
b) аз хамаи намудхои андоз ва пардохтхои гумрукй озод шуданд
c) сохибкорон сохиби маблағи иловагй гаштанд

5. Мувофиқ ба матни хондашуда фардои сохибкорй дар Точикистон чигуна ба назар мерасад?
a) дурахшон
b) номаълум
c) бефойда

Машқи 2: Калимахои хаммаъноро мувофиқат намоед. (Match the synonyms in the following table.)

\begin{tabular}{|l|ll|}
\hline 1. & самт & вазифадор намудан \\
2. & $\circ \quad$ паём & $\circ$ \\
3. & таъмин намудан & рози кардан \\
4. & супориш додан & баёния \\
5. & қонеь кардан & фарохам овардан \\
\hline
\end{tabular}

Машқи 3: Барои чумлахои дуруст харфи [Д], ва барои чумлахои нодуруст харфи [Н] - ро интихоб намоед? (Choose [Д] for the true statements and $[\mathrm{H}]$ for the false.)

1. Яке аз сабабхои инкишоф ёфтани сохаи сохибкорй дар Точикистон ин зиёд намудани фоизи хамаи намудхои андозхо мебошад. [Д/Н]

2. Давлат фаъолиятхои сохибкоронро дастгирй намекунад. [Д/Н]

3. Дар суханронии худ раиси Чумхурии Точикистон зикр намуд, ки дар солхои оянда низ тадбирхои судманд оид ба рушшди иқтисодиёти мамлакат идома дода шаванд. [Д/Н]

4. Консепсияи оид ба рушди сохибкорй дар соли 2004 лағв шуд. [Д/H]

5. Сахми сохибкорон дар рушди иқтисодиву ичтимой, созандагиву бунёдкории мамлакат хеле зиёд аст. [Д/Н] 
Машқи 4: Чумлахоро мувофиқи маъно/замон бо истифода аз калимахои дар қавс оварда шуда ба охир расонед. (Complete the following sentences with the appropriate word/form of the verbs in parenthesis.)

1. Рохбари давлат дар зикр намуданд, ки барои фаолият намудани сохибкорон шароити хуб фарохам овардан зарур аст. (суханрони/таклиф)

2. Консепсия оид ба руушди сохаи сохибкорй дар мохи декабри соли 2004 он ба дастгирии давлатии сохибкорй равона гардидааст. (сертификатсия/ қабул гардид)

3. Сардори давлат дар паёмаш ба Хукумати кишвар ва дигар сохторхои дахлдор супоришхои мушаххас дода, аз чумла қайд намудааст, ки ихтисори пурраи андоз аз чакана бардошта шавад. (харид/фурӯш)

4. Чи тавре, ки аз суханронии Сардори давлат бар меояд, сахми дар раванди созандагиву бунёдкорй, рӯшди иқтисодиву ичтимоии мамлакат бенихоят бузург аст. (точирони кишвар/ кумитаи давлатии сармоягузорй)

5. ва Хукумати кишвар ба инкишоф ва мақоми арзишманди ичтимоии сохибкорон дар раванди бозсозии кишвар таваччухи хоса зохир менамоянд. (сиёсатмадорон/ давлат) 


\title{
CHAPTER 10: BLOOD PRESSURE AND HEALTH
}

\author{
Фишори Хун Ва Тандурустй
}

Оё Шумо аз фишорбаландии хуни худ, ки он чанд аст, огохй доред? Маълум, ки не! Ба андешаи коршиносон ба ин суол танхо сеюмин шахс посух гуфта метавонад. Бояд таъкид кард: онхое, ки фишори худро зери назорат гирифта метавонанд, аз чанд бемории дигар низ рахой меёбанд. ${ }^{1}$ Пушшида нест, ки фишори инсон тағйирёбанда буда, дар давоми шабу рузз чанд маротиба пасту баланд шуданаш аз эхтимол дур нест. Баъзан мешавад, ки рӯзона фишор боло мераваду шабона поён мефарояд, ё баръакс. Хамчунин, дар мавридхои тағйирёбии обу хаво, якбора ба хаячон омадан ё ки афзудани хастагии чисмонй фишори хун ру ба тағйирот оварданаш мумкин аст. Рафта - рафта равони инсон ба ин хама чунон одат мекунад, ки дар аснои такроран болоравии фишор хангоми бахаячонойй бемор онро чун меъёри муқаррарй мепиндорад.

Мувофиқ ба маълумотхои оморй имрӯз 40 фоизи ахолй аз бемории фишорбаландй азият мекашанд, ки аз онхо танхо нисфашон машғули назорат кардани фишори худ мебошанд ва хангоми сар задани фишор ба маслихати духтур риоя мекунанд. Боқимондахо ё бемории худро хис намекунанд ё ки бехабар аз бемории чиддй будани он табобати мунтазамро сарфи назар мекунанд.

Бояд донист, ки фишори устувор дар рагхои хунгард (артерияхо артериолахо) тағйирот ба амал оварда, ба варамида ғафстар ва баъди фосилае тангтар шудани рагхо мусоидат мекунад. Ин ба он меоварад, ки меъёри хунгардй афзуда, кори дилро барзиёд намояд. Пас дар ин хангом чй бояд кард? Бояд донист, ки ин холат боиси ба хатари чиддй, аз чумла сактаи қалб ва сактаи майна (инфаркт ва инсулт) дучор шудан мусоидат мекунад.

\section{Омилхои тахрикдиханда кадоманд?}

Оғози ин хама аз чист? Омилхо зиёданд. Аз чумла: бахаячонойй (стресс). Хамагон нағз медонанд, ки бидуни бахаячонойй зистро тасаввур кардан душвор аст. Ин холат чаро хавфнок аст? Дар вазъияти бахаячонойй ғадудхои болоии гурда ба рагхо бештар моддахоро равона мекунанд, ки он ба задани қалб ва рагхои хунгард зарба оварда, ба баландшавии фишор боис мешавад.

\footnotetext{
${ }^{1}$ Бояд таъкид кард 'it must be emphasized' is an impersonal construction. The main verbs in this type of Tajik impersonal constructions always remain in the past stem form. The common impersonal constructions in this category are (a) бояд + past stem stem 'one must/one has to ...' (b) метовон + past stem stem 'one can ...' (c) мешавад + past stem stem 'one can/may . . .'/'it is possible to ...' (d) мешуд + past stem stem 'one could [have]/it was possible to. ..' For more see, in John R. Perry, A Tajik Persian Reference Grammar (Leiden, Boston: Brill Academic Publishers: 2005), 330-44.
} 
Дар чунин холат бемор бояд чй кор кунад? Маслихат медихем, ки худро ором нигох дошта, нисбати хар гуна масъалахои руузгор, андешахои дар сар дошта фикр накунад. Донад, ки мушкиливу сахтии рӯзгор гузаранда асту набояд аз он ғам хӯрд.

Тамоку (курение). Сигор, ки дар таркибаш никотин мавчуд аст, на танхо ба баланд шудани фишор мусоидат мекунад, балки таъмини хунро дар рагхо халалдор карда, ба он оварда мерасонад, ки задани қалб аз меъёри муқаррарй баландтар шавад.

Дар ин вазъ маслихат дода мешавад: аз кашидани тамоку худдорй намоед.

(Text taken from the newspaper Сухани халк, August 04, 2011)

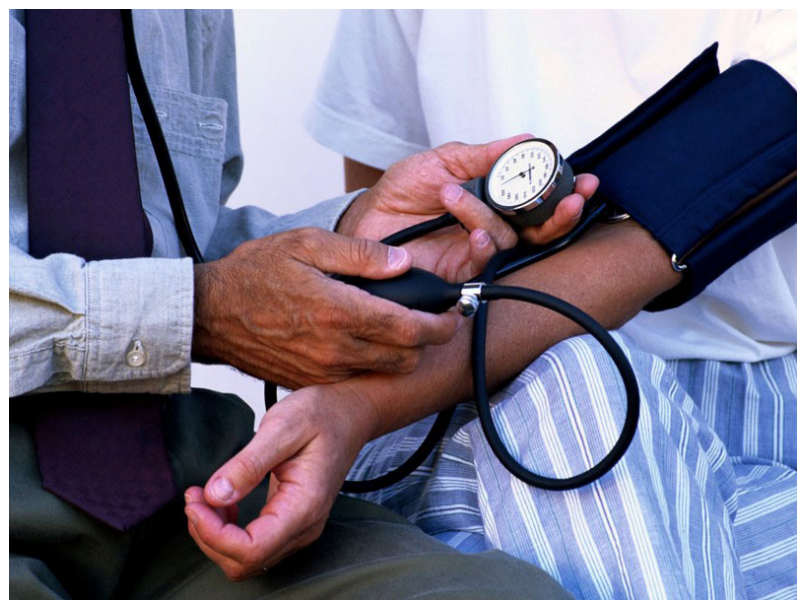

(Blood pressure measurement) ${ }^{2}$

\section{VOCABULARY}

артерия (n.) - artery

acно (n.) - time, period of time

ахолй (n.) - population

баланд (adj.) - high

барзиёд (adj.) - excess, surplus

бахаячфонойй (n.) - stress

Баъзан (adv.) - sometimes, occasionally

бемор (adj.) - a sick person беморй (n.) - disease

бехабар (adj.) - unaware

боқимонда (adj.)- the rest of people

варамида (adj.) - swollen

ғадуд (n.) - gland

ғафс (adj.) - thick

гипертония (n.)-hypertension

гурда (n.) - kidney

\footnotetext{
${ }^{2}$ Blood pressure measurement. Copyright holder www.volganet.ru; Image source Wikimedia Commons, https://commons.wikimedia.org/wiki/File:Blood pressure measurement (2009).jpg
} 


$$
\begin{array}{ll}
\text { дил (п.) - heart } & \text { сакта (n.) - stroke } \\
\text { духтур (n.) - doctor } & \text { сактаи қалб (Russian: инфаркт) (n.) } \\
\text { зиёд (adj.) - many } & \text {-heart attack } \\
\text { маврид (n.) - case } & \begin{array}{l}
\text { сактаи майна (Russian: инсулт) - } \\
\text { stroke }
\end{array} \\
\text { майна (n.) - brain } & \begin{array}{l}
\text { сарфи назар кардан - to dispense } \\
\text { маслихат (n.) - advice }
\end{array} \\
\text { мась, to relinquish, to forgo } \\
\text { меъёр (n.) - level } & \text { сигор (n.) - cigarette } \\
\text { модда (n.) - elements, ferment } & \text { табобат (n.) - treatment } \\
\text { мувофиқ (adj.) - appropriate } & \text { тағйирёбанда (adj.) - changing, } \\
\text { муқаррарй (adj.) - usual, normal } & \text { сhаngeable, variable } \\
\text { мунтазам (adj.) - regular, systematic, } & \text { такроран (adv.) - repeatedly } \\
\text { in order } & \text { танг (adj.) - narrow } \\
\text { мусоидат мекунад (v.) - to help, to } & \text { таркиб (n.) - composition, structure, } \\
\text { аssist } & \text { sуnthesis } \\
\text { назорат (n.) - supervision, check } & \text { устувор (adj./adv.) - stable, firm, } \\
\text { обу хаво (n.) - weather } & \text { stеady, staunch } \\
\text { огохй (n.) - information, notice, } & \text { фишорбаландй (adj.) - high blood } \\
\text { поtification } & \text { рressure } \\
\text { худдорй намудан (v.) - to desist, to } & \text { фоиз (n.) - percent } \\
\text { refrain } & \text { фосила (n.) - interval } \\
\text { омил (n)- reason } & \text { хавфнок (adj.) - dangerous } \\
\text { паст (adj.) - low } & \text { хатар (adj.) - danger } \\
\text { равон (n.) - spirit, psyche, mind, } \\
\text { intellect } \\
\text { раг (n.) - vein, artery } \\
\text { рагхои хунгард (n.) - blood vessels } \\
\text { риоя кардан (v.) - to respect, to } \\
\text { оbserve, to keep, to follow }
\end{array}
$$




\section{EXERCISES}

Машқи 1: Чавоби дурустро интихоб намоед. (Choose the correct answer.)

1. "Гипертония" яъне чй?
a) пастшавии фишори хун
b) камхунй
c) баландшавии фишори хун

2. Чанд фоизи ахолй ба бемории фишорбаландй гирифторанд?
a) $50 \%$
b) $40 \%$
c) $20 \%$

3. Омили асосии ба амал омадани фишорбаландй дар чист?
a) депрессия (рӯхафтодагй)
b) стресс (бахаячонойй)
c) анемия (камхунй)

4. Чаро бахаячонойй барои инсон хавфнок аст?
a) фишори хунро баланд мекунад
b) дили шахсро ором нигох медорад
c) ба камхуни мерасонад

5. Дар таркиби сигор чи гуна модда вучуд дорад, ки ба баланд шудани фишор оварда мерасонад?
а) глюкоза
b) охан
c) никотин

Машқи 2: Калимахои хаммаъноро мувофиқат намоед. (Match the synonyms in the following table.)
1. маслихат
$\circ \quad \operatorname{coxT}$
2. тағйирёбанда
○ қалб
3. дил
○ машварат
4. таркиб
5. майна
○ мағ3
○ ивазшаванда 
Машқи 3: Барои чумлахои дуруст харфи [Д], ва барои чумлахои нодуруст харфи [Н] - ро интихоб намоед? (Choose [Д] for the true statements and $[\mathrm{H}]$ for the false.)

1. Шахсоне, ки фишори худро зери назорат мегиранд, аз чанд бемории дигар рахой меёбанд. [Д/Н]

2. Тағйирёбии обу хаво ба афзудани фишори хун таъсир намерасонад. [Д/H]

3. Фишори устувор дар рагхои хунгард тағйирот ба амал меоварад. [Д/H]

4. Никотин ба паст шудани фишор мусоидат мекунад. [Д/Н]

5. Мувофиқи маълумотхои оморй, имрӯз аз ним зиёди ахолй аз бемории фишорбаландй азият мекашанд. [Д/Н]

Машқи 4: Чумлахоро мувофиқи маъно ё замон бо истифода аз калимахои дар қавс оварда шуда ба охир расонед. (Complete the following sentences with the appropriate word/form of the verbs in parenthesis.)

1. Барои назорат кардани фишори худ, бояд машваратхои духтуронро риоя намоянд. (беморон/ табибон ).

2. Омилхои гуногун, фишорбаландии хунро (чустан /ба вучуд овардан).

3. Дар вазъияти бахаячонойй дар рагхои хунгард тағйирот (бастан /рўй додан).

4. Табибон ба маризон машварат медиханд, ки ба хар гуна масъалахои рӯзгор надиханд, зеро хама мушкилихои рӯзгор гузарандаанд. (таваччӯх/дилгармй)

5. Беморон бояд аз истифодаи тамоку . (зиёд намудан/худдори намудан) 


\section{CHAPTER 11: CAN AN OLD MAID BE LUCKY?}

\section{Пирдухтар хушбахт мешавад?}

Дар кишвари мо ақидае чорй гаштааст, ки агар духтар то 30 солагй ба шавхар набарояд, пирдухтар мемонад. Барои бахти накушодаи духтари 30-сола атрофиёну наздикон ба шигифт афтода, доим аз паяш назора мебаранду бо суоли «кай шавхар мекунй?» духтари бечораро чонбезор мекунанд.

Инак, бахт ба руй̆и пирдухтар хандид. Шумо баъди 30 - солагй бори аввал ба шавхар мебароед. Мо шуморо табрик мекунем. Издивоч баъди 30 - солагй душворихои худро дорад, аз ин хотир қарор додем дар бораи камбудиву бартарихои издивоч баъди 30 солагй каме маълумот дихем.

\section{Чихатхои манфй}

Бо рафтани синну сол доираи дӯстон танг мешавад. Агар шумо дар ягон чой кор намекарда бошед 1 , чустучӯи шавхар бароятон душвор мегардад. Вохимаи атрофиён духтарро водор менамояд, ки ба хостгори пешомада дархол розигй дихад. Фарз кардем, ки хешовандон ба шумо фишор намеоранду атрофатон пур аз харидор аст. Тўй баргузор гашт, вале ханӯз барои нафаси осуда кашидан барвақт аст, чунки дар хаёти оилавй мушкилихо пеш меоянд.

Шумо - ду нафар шахсияте хастед, ки аллакай одату тарзи зиндагии худро доред. Оё якчоя буда метавонед? Хардутон ними умр танхо барои худ зиндагй кардаеду акнун ду нафар шудед. Оё ба камбудихову бехунарии якдигар чашм пушшида метавонед?

Баъди 30 солагй издивоч намуда, бояд боз фарзанддор хам шавед. Рафту 2 - 3 фарзанд хохед? Бо рафтани синну сол имкони таваллуд кардани фарзанди солим кам мешавад. Шуморо лозим меояд, ки дархол баъди таваллуди тифли якум тифли дуюмро низ ба нақша гиред.

\section{Чихатхои мусб̄̄}

Агар ба чихатхои манфии издивочи дер ахамият дихем, чихатхои мусбияш хам пайдо мешаванд.

Домоду арӯси 30 сола хеле хуб дарк менамоянд, ки аз издивоч чй мехоханд ва чаро махз хамин нафарро интихоб намудаанд. Агар ба камбудихои кӯчаки якдигар чашм пӯшидаю гузашт карда тавонед, зиндагии якчоя он қадар хам вахмангез намешавад. Шумо метавонед бо якдигар маслихат карда ба як қарор биёед. Минбаъд асабй нашуда, аз хар гапи ночиз муноқиша намеороед. Нисбати якдигар хурмату эхтиром пайдо мекунед. Тибқи омор, махз бо сабаби бо якдигар ху нагирифтан,

${ }^{1}$ Агар шумо дар ягон чзой кор намекарда бошед 'if you do not work somewhere' is a conditional sentence. 
чунин оилахо вайрон мешаванд. Дар ин синну сол хам марду хам зан бояд аллакай мавқеи худро дар чамъият ёфта бошанд². Баъди издивоч дархол барои фарзанддор шудан бояд кӯшиш намуд. Одатан мардхо баъди 35 солагй оиларо сахт меқапанд, чунки ба оиладори рӯхан омода мешаванд. ${ }^{3}$

(Text taken from the newspaper Оила, June, 20, 2012)

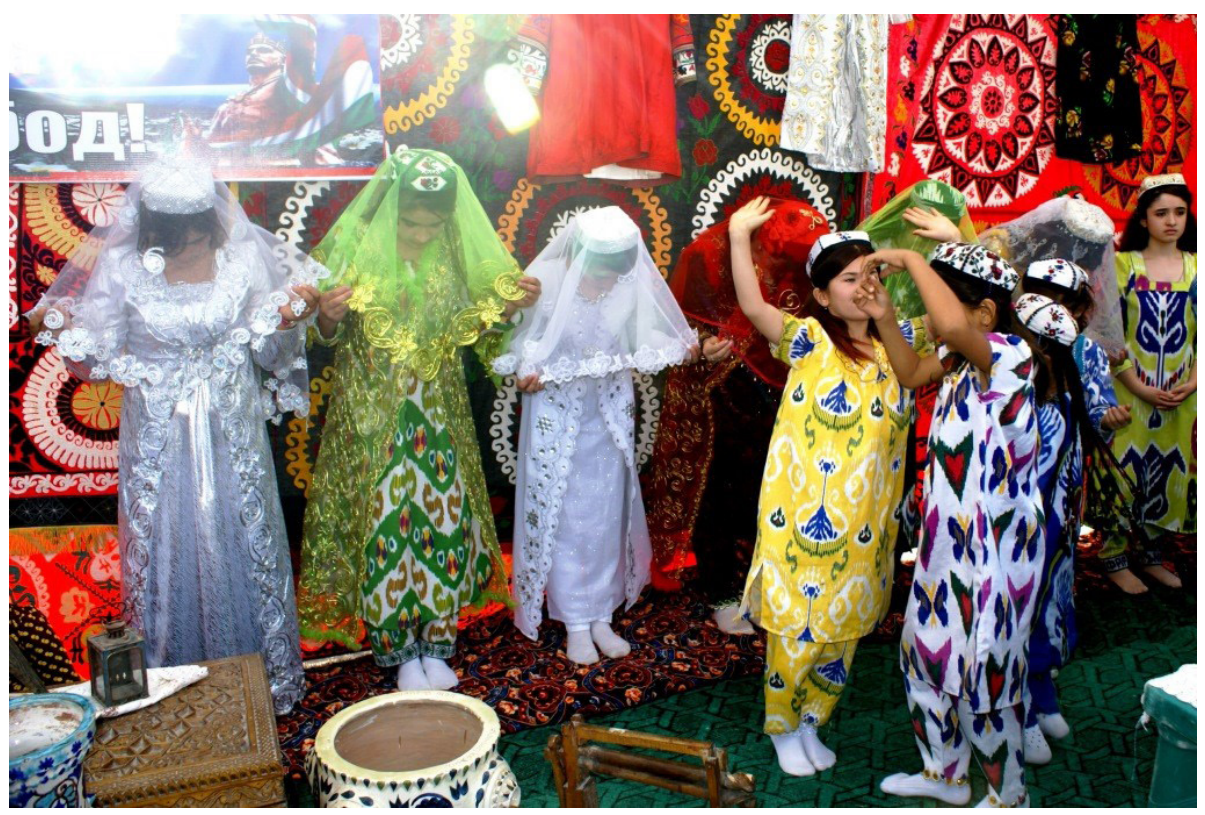

(Tajik Wedding Ceremony) $^{4}$

\footnotetext{
${ }^{2}$ Past subjunctive (must have gotten/received).

${ }^{3}$ For wedding rituals in Tajikistan, see Sophie Roche and Sophie Hohmann, "Wedding Rituals and the Struggle over National Identities" in Transformation of Tajikistan: The Sources of Statehood, (ed.) John Heathershaw, Edmund Herzig (New York: Routledge, 2013), 127-42.

4 Tajik wedding ceremony. Image source Wikimedia Commons, https://commons.wikimedia.org/wiki/File:\%D0\%A1\%D0\%B2\%D0\%B0\%D0\%B4\%D0\%B5\%D0\%B1\%D0\%BD $\%$ D0\%B0\%D1\%8F \%D1\%86\%D0\%B5\%D1\%80\%D0\%B5\%D0\%BC\%D0\%BE\%D0\%BD\%D0\%B8\%D1\%8F (\%D0\%9D\%D0\%B5\%D0\%B2\%D0\%B5\%D1\%81\%D1\%82\%D1\%8B, $\%$ D0 $\% 93 \%$ D0 $\%$ B $8 \%$ D1 $\% 81 \%$ D1\%81\%D0\%B0\%D1\%80).JPG
} 


\section{VOCABULARY}

аллакай (adv.) - already

apȳc (n.) - bride

асабй шудан (v.) - to get nervous

aтpoф (n.) - surroundings, sides

атрофиёну наздикон - relatives and neighbors

ачиб (adj.) - wonderful

ба шавхар баромадан (v.) - to marry

барвақт (adj./adv.) - early

бартарй (n.) - superiority

бахт (n.) - fate, luck

водор намудан (v.) - to compel, to force

вохима (n.) - alarm, fear, panic

дархол (adv.) - presently, immediately, at once

домод (n.) - groom

доно (n.) - smart

душвор (n.) - difficulty, problem

душворй (n.) - difficulty

издивоч (n.) - marriage

Инак - now; Behold!, lo!

интихоб намуданд (v.) - to make a choice

камбудй (n.) - shortcoming, flaw

қарор додан (v.) - to decide, to make up one's mind

муноқиша (n.) - conflict, discord

мусбй (adj.) - positive

мутаваччех шудан (v.) - to pay attention

нафаси осуда кашидан - to relax, to be relieved

пирдухтар (n.) - old unmarried girl, spinster

пурсучӯй (n.) - search

рафту... - and what if

розй шудан (v.) - agree

розигй додан (v.) - agree

сахт нигох доштан (v.) - to keep

синну сол (n.) - age

солим (adj.) - healthy

таваллуд кардан (v.) - to give a birth

тибқи омор (n.) - according to statistics

тифл (n.) - child

тӯй (n.) - festival, wedding

фарз кардан (v.) - suppose

фарзанд (n.) - child

фозил (adj.) - erudite

харидор (n.) - literal meaning buyer, but it simply means suitor in this context.

хешовандон (n.) - relatives

хостан (v.) - to want

хостгор (n.) - suitor

хушбахт (adj.) - happy, lucky

хаёти оилавй (n.) - family life

хамсоя (n.) - neighbor

чихат (n.) - side

чонбезор (adj.) - dejected, disappointed with life

чустучӯ (n.) - search 


\section{EXERCISES}

Машқи 1: Чавоби дурустро интихоб намоед. (Choose the correct answer.)

1. Духтаре, ки ба шавхар намебарояд, урро чй ном мебаранд?
a) пиразан
b) пирдухтар
c) пирамард

2. Агар бахт ба рӯйи духтари бечора нахандиду то 30 солагй шавхар накард, одатан урро кихо ба ташвиш меоранд?
a) бегонахо
b) мехмонон
c) атрофиён

3. Барои духтар, издивоч баъд аз 30 солагй чй мушкилихо дорад?
a) имкони гирифтани маълумоти олй
b) имкони таваллуд кардани фарзанди носолим
c) ёфтани чуфти муносиб

4. Аз рӯйи матни хондашуда, мардхо одатан дар синнй чанд солагй оиларо сахт мекапанд?
a) баъди аз 35 солагй
b) то 30 солагй
c) баъд аз 30 солагй

5. Агар ин навхонадорон ба камбудихои кутчаки якдигар чашм пушшидаю бахшида тавонанд, зиндагиашон чй ранг мегирад?
a) дар зиндагй муноқишаи зиёд мекунанд
b) аз хамдигар чудо мешаванд
c) зиндагй дар назарашон вахмангез наметобад

Машқи 2: Калимахои хаммаъноро мувофиқат намоед. (Match the synonyms in the following table.)

\begin{tabular}{|l|l|}
\hline 1. & чустучу \\
2. вохима & $\circ \quad$ харос \\
3. чихат & $\circ \quad$ некбахт \\
4. хушбахт & $\circ \quad$ тараф \\
5. домод & $\circ \quad$ шах \\
\hline
\end{tabular}


Машқи 3: Барои чумлахои дуруст харфи [Д], ва барои чумлахои нодуруст харфи $[\mathrm{H}]$ - ро интихоб намоед? (Choose [Д] for the true statements and $[\mathrm{H}]$ for the false.)

1. Агар шумо дар ягон чой кор мекарда бошед, чустучӯи шавхар бароятон душвор намегардад. [Д/Н]

2. Бо рафтани синну сол дӯстон бисёр мешаванд. [Д/Н]

3. Зиндагии якчоя чихатхои манфй ва мусбии худро дорад. [Д/H]

4. Мардхо одатан баъд аз бисту панч солагй ба оиладори руххан омода мешаванд. [Д/Н]

5. Пирдухтар баъд аз ба шавхар баромаданаш бояд дархол барои фарзанддор шудан кӯшиш намояд. [Д/Н]

Машқи 4: Чумлахоро мувофиқи маъно/замон бо истифода аз калимахои дар қавс оварда шуда ба охир расонед. (Complete the following sentences with the appropriate word/form of the verbs in parenthesis.)

1. Дар Точикистон фикре ба вучуд омадааст ки духтар агар то 30 солагй издивоч накунад, пирдухтар . ( хонадор шудан/боқй мондан)

2. Рафтори атрофиён духтари бечораро водор менамояд, ки ба

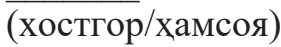
пешомада дархол розигй дода ба шавхар барояд.

3. Муносибатхои оилавй чихатхои (хурду калон/хубу бад)

худро дорад.

4. Вақте, ки умри инсон боло меравад, имкони куддаки солим хам кам мешавад. (парвариш кардан/ба дунё овардан)

5. Мувоффиқи оморхо, оилахое, ки мешаванд, сабаби аслияш ин якдигарнофахмй байни зану шавхар аст. (мепайванданд/чудо) 


\section{CHAPTER 12: NAVRUZ FESTIVAL}

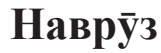

Оид ба иди Наврӯз маъхазу асотир ба таври гуногун қисса мекунанд. Чунончи, дар замони салтанати Сомониён Наврӯзро шаш рӯз ид мекарданд. Дар ибтидо онро барзгарон чашн мегирифтанд, ки он Наврӯзи кишоварзон ном дошт. Гумон меравад, ки 6 рузз чашн гирифтани Наврӯз сахехтар аст, зеро дар рўзи аввал тибқи анъана шахси сохибэътибор Амири Наврӯз интихоб мешуду танхо 5 рӯз хукм меронд.

Пас, чашни фархундаи Наврӯз барои мардуми ориёнажод азизу муққадас аст. Ин чашн, ки таърихи туллонй дорад, дар масири рӯзгори мардуми ориёй як падидаи неки олам мебошад, ки хамеша инсонхоро барои зиндагии ширин ва руззгори беолоиш хидоят намудааст ва ба зебопарастй, назокату тозакорй ва дӯст доштани мухити зист водор месозад.

Пас аз истилои Осиёи Миёна аз тарафи арабхо чашни Наврӯз манъ шуд. Таърих гувох аст, ки бегонагони ғосиб борхо кушшида буданд, ки ин чашнхои мардумиро ба олами нестй бубаранд ва аз хотири мардум бизудоянд, вале хушбахтона, бар хилофи чашмдошти нотавонбинон ин мероси ачдодй беш аз пеш пурчилотару шукӯхмандтар тачлил мегардад. Дар замони Иттиходи Шурравй бо сабабхои гуногун Наврӯз расман тачлил намешуд, танхо соли 1978 бо қарори Хукумати Чумхурии Точикистон иди Наврӯз чун анъанаи ниёгон ба расмият даромад. Имрӯз ба шарофати истиқлолият Наврӯзро бо шукӯху шахомат истиқбол мекунем. Ва ин чашн дар рўзхои мо аз пештара дида ${ }^{1}$ бештар хусусияти умумихалқиро гирифтааст.

\section{Ширкати донишчууён дар иди Наврӯз}

Бахри мутантан тачлил намудани иди Наврӯзи имсола, ки чашни байналмилалй эълон гардидааст, дар гӯшаву канори чумхурй омодагихо идома доранд.

Аз чумла, дар Донишгохи миллии Точикистон барои боз хам шукуххманд гузаронидани чашни Наврӯз донишчуё̈ну устодон тайёрии хуб мебинанд. Хафтаи равон ба ин муносибат дар шахраки донишчуё̈н чамъомад доир гардид, ки дар он кулли донишчуё̈н иштирок намуданд. Дар чамъомад рохбарони ДМТ ${ }^{2}$ зикр намуданд, ки барои иштирок дар чашни Навруззи имсола зиёда аз 5 хазор донишчӯ сафарбар шудаанд, ки аз ин 2700 нафарашон аз Донишгохи миллии Точикистон мебошанд.

\footnotetext{
${ }^{1}$ Дида is used as an emphatic, meaning perceptibly, with comparative adjectives and adverbs. For example, Шумо мошинро аз ман дида охистатар меронед. Духтарони точик дар муқоиса бо духтарони дигар кишвархои Осиёи Марказй дида зеботаранд.

2 Донишгохи Миллии Точикистон
} 
Хамчунин, зикр шуд, ки донишчуё̈н чихати тахияи барномахои навруузй дар ду баст ширкат менамоянд.

Аз 10-уми феврал як қисми донишчӯён дар варзишгохи марказй ва қисмати дигар дар Навруузгох (собиқ Ипподром) ба тамрин оғоз менамоянд. ${ }^{3}$

(Texts taken from newspaper Омўзгор February 11, 2011)

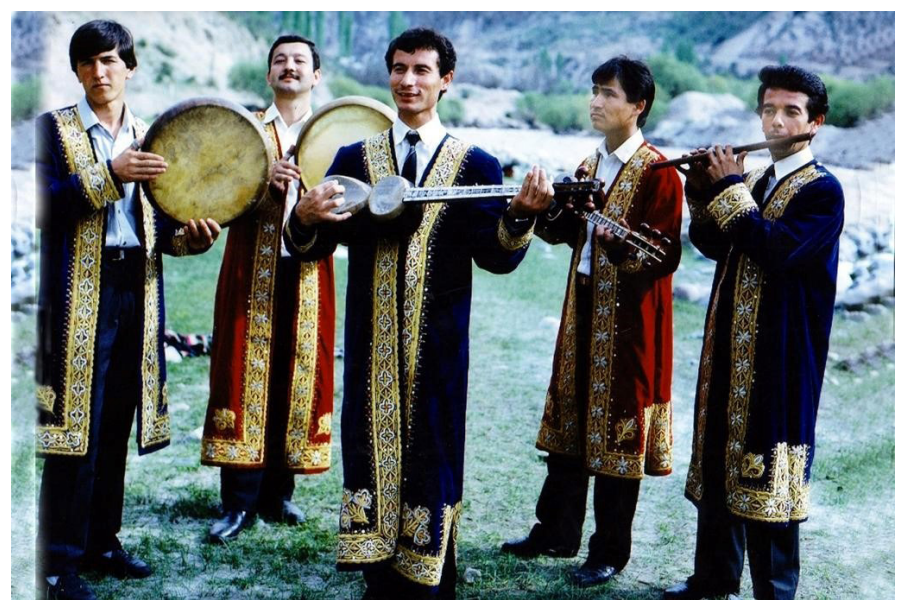

(Tajik students celebrating Navruz) ${ }^{4}$

\section{VOCABULARY}

Азиз (adj.) - dear

Анъана (n.) - tradition

ба шарофати - thanks to, by virtue of

Барзгар (n.) |Pl. Барзгарон $\mid$ - farmer

Баст (n.) - shift; bundle

Бахри - for, for the sake of, in the interest of

Бегона (adj.) |бегонагон| - foreign, alien
Водор сохтан (v.) - to oblige, to force

Ғосиб (adj.) - aggressor

Гумон (n.) - thought, opinion; suspicion

Гумон меравад, ки - it is thought that Дар Замони (n.) - in the period of Зебопарастй (adj.) - love of beauty, aestheticism

Зиндагӣ (n.) - life

\footnotetext{
${ }^{3}$ For a detailed discussion of history of Navruz, see Mary Boyce, "NOWRUZ i. In the Pre-Islamic Period," Encyclopcedia Iranica, online edition, 2016, available at http://www.iranicaonline.org/articles/nowruz-i (accessed on 19 May 2016)

${ }^{4}$ Tajik student's ensemble. Image source Wikimedia Commons, https://commons.wikimedia. org/wiki/File:\%D0\%9F\%D0\%B5\%D1\%81\%D0\%BD\%D1\%8F \%D0\%BC\%D0\%BE\%D0\%BB $\%$ D0\%BE\%D0\%B4\%D1\%91\%D0\%B6\%D0\%B8.jpg
} 
Зудудан (v.) $\mid$ Зудо(й) $\mid$ - to file away, to wipe, to clean, to remove

Ид Кардан (v.) - to celebrate

Истило (n.) - conquest, ascendency, domination

Кишоварз (n.) |Pl. Кишоварзон|farmer

Манъ шудан (v.) - to become forbidden

мардум (n). - people

муққадас (adj.) - holy, sacred

Мутантан (adj.) - splendid, luxurious, extravagant

Мухити зист (n.) - environment

Наврӯз (n.) - Nowruz holiday

Назокат (adj.) - elegance, delicateness, courtesy, refinement

Нек (adj.) - good, glorious

Нестй (n.) - non-existence

Ниёгон (n.) - ancestors

Нотавонбин (adj.) |нотавонбинон|envious, hateful

Олам (n.) - world, universal

Ориёйй, Ориёнажод (n.) - Aryan

Пештара (adj.) - former, previous

Пурчило (adj.) - shining, glittering, bright

Рӯзгор (n.) - life; time, period
Салтанати Сомониён (n.) - Samanid Sultanate

Caxex (adj.) - true

Сохибэътибор (adj.) - respected, honorable

Тачлил намудан (v.) - to glorify, to honor

Таърих (adj.) - history

Тозакорй (adj.) - cleanliness, purity, tidiness

Турлонй (adj.) - long

Умумихалқй (adj.) - general, public

Устура (n.) |Pl. Асотир $\mid$ - myth, legend

Фархунда (n.) - happy, prosperous

Хилоф (adj.) - contrary, opposite

Хотир (n.) - memory

Хушбахтона (adj., adv.) - fortunately

Хидоят намудан (v.) - to guide, to instruct

Хукм рондан (v.) - to rule

Чамъомад (n.) - congregation

Чашн гирифтан (v.) - to celebrate

Шахомат (n.) - spirit, courage

Шахраки донишчӯён - it refers to the Tajikistan National University campus and the surrounding area

Ширин (adj.) - sweet

Шукӯх (n.) - grandeur, splendor 


\section{EXERCISES}

Машқи 1: Чавоби дурустро интихоб намоед. (Choose the correct answer.)

1. Дар давраи салтанати Сомониён Наврӯзро чанд рӯз чашн мегирифтанд?
a) як рӯз
b) панч рӯз
c) шаш руз3

2. Кадом яке аз ин қабилахо Наврӯзро дар замони қадим чашн мегириф?
a) қабилахои ориёйй
b) қабилахои араб
c) қабилахои аврупойй

3. Дар замони Иттиходи Шурравй чашнгирии иди Наврӯз дар кадом сол ба расмият даромад?
a) 1924
b) 1978
c) 1991

4. Чанд нафар донишчӯён иштирокашон дар гузаронидани чорабинии Наврӯзй зикр шуд?
a) 5000
b) 2700
c) 2000

5. Мувофиқи матни дар боло зикршуда тамрини барномаи имсолаи Наврӯзй дар кучо гузаронида мешавад?
a) дар Навруузгох
b) дар Донишгохи Миллии Точикистон
c) дар назди китобхонаи миллй

Машқи 2: Калимахои хамаъноро мувофиқат намоед. (Match the synonyms in the following table.)

\begin{tabular}{|l|l|}
\hline 1. Хилоф & $\circ$ ба хотири \\
2. Бахри & $\circ$ барои \\
3. Бахри & $\circ$ чахон \\
4. Зиндагй & $\circ$ зид \\
5. Олам & $\circ$ хаёт \\
\hline
\end{tabular}


Машқи 3: Барои чумлахои дуруст харфи [Д], ва барои чумлахои нодуруст харфи [H] - ро интихоб намоед? (Choose [Д] for the true statements and $[\mathrm{H}]$ for the false.)

1. Чашни иди Наврӯз барои мардуми ориёнажод хело мухим ва муққадас аст. [Д/Н]

2. Наврӯз яке аз идхои миллии мардуми точик ба шумор рафта, танхо дар Точикистон чашн гирифта мешавад. [Д/Н]

3. Истилогарони араб баъд аз запт намудани Осиёи Миёна чашнгирии иди Наврӯзро миллй намуданд. [Д/Н]

4. Донишчуё̈н ба хотири дар сатхи баланд гузаронидани барномаи наврӯзй дар ду бахш тамрин менамуданд. [Д/Н]

5. Бо шарофати истиқлолият имрӯз Наврӯзро дар хама гӯшаву канори Чумхурии Точикистон бо як шукухху шахомати баланд чашн мегиранд. [Д/Н]

Машқи 4: Чумлахоро мувофиқи маъно/замон бо истифода аз калимахои дар қавс оварда шуда ба охир расонед. (Complete the following sentences with the appropriate word/form of the verbs in parenthesis.)

1. Мардуми точик анъанахои ниёгонашонро (нишастан/давом додан)

2. Бо шарофати иди Наврӯз дар Точикистон сатхи иди миллиро гирифт. (истиқлолият/иди Вахдат).

3. Ба хотири хубу рангоранг гузаронидани барномахои Наврӯзии имсола, мардуми точик дар тамоми шахру навохии мамлакат дида истодаанд. (тайёрй/дилсардй)

4. Тачлили иди Наврӯз аз пештара дида, имрӯз бештар хусусиятхои умумихалқиро навиштан)

5. Рохбарони Донишгохи миллии Точикистон дар вохурияшон оид ба барномаи Наврӯзи имсола, қайд намуданд, ки барои дар чашни Наврӯзи имсола хазорхо донишчуёё сафарбар карда мешаванд. (ширкат/сарвазир) 
KEY TO EXERCISES 


\section{KEY TO EXERCISES}

\section{CHAPTER 1: The SAMANID SATE STRUCTURE}

Exercise 1: 1. b, 2. c, 3. c, 4. b, 5. a

Exercise 2:

1. Мутаносиб

3. мақом

2. Шароит

1. мувоффиқ

3. Мансаб

5. амали намудан

4. Хазина

2. вазъият

5. Чорй намудан

4. Ганчина

Exercise 3: 1. Н, 2. Д, 3. Н, 4. Д, 5. Н

Exercise 4: 1. робитахои, 2. мешуданд, 3. буд, 4. даст мезаданд, 5. нӯшокихои масткунанда)

\section{CHAPTER 2: STATUES OF BUDDHA}

Exercise 1: 1. a, 2. b, 3. a, 4. c, 5. c

Exercise 2:

1. Қисм

2. Дучор шудан

3. барахна

3. Луч

5. мучасама

4. Тасаввур кардан

1. пора

5. Хайкал

2. py ба рӯ шудан

4. хаёл кардан

Exercise 3: 1. Н, 2. Д, 3. Д, 4. Н, 5. H

Exercise 4: 1. дарёфт шуд, 2. сиёх ё кабуд, 3. дигар, 4. нишон дода мешуданд, 5. иборат буда

\section{CHAPTER 3: ABŪ ABDULLĀH RŪDAKI}

Exercise 1: 1. c, 2. a, 3. c, 4. b, 5. a

Exercise 2:
1. Солор
5. комил
2. Парниён
4. тифл
3. Бевосита
1. pохбар
4. Куудак
3. мустақим
5. пурра
2. абрешим

Exercise 3: 1. Д, 2. Н, 3. Д, 4. Д, 5. Н

Exercise 4: 1. шеъри, 2. шоирон, 3. ашъори, 4. гузошта, 5. меояд 


\section{CHAPTER 4: RUSSIAN OCCUPATION OF CENTRAL ASIA}

Exercise 1: 1. c, 2. c, 3. b, 4. a, 5. b

Exercise 2:
1. Забт
2. Мустақил
3. рохбар
3. Сардор
4. фоида
4. Манфиат
5. чойгох
5. Мавкеь
2. озод
1. ишғол

Exercise 3: 1. H, 2. H, 3. H, 4. Д, 5. H

Exercise 4: 1. аз, 2. замини, 3. мубориза мебурданд, 4. ишғол намуданд, 5. баста шуд

\section{CHAPTER 5: MIRZO TURSUNZODA}

Exercise 1: 1. a, 2. b, 3. c, 4. b, 5. c

Exercise 2:
1. Толибилм
3. дилписанд
2. Маъмурият
1. хонанда
3. Форам
5. шоиста
4. Худуд
2. мудирият
5. Лаёқатманд
4. атроф

Exercise 3: 1. Н, 2. Н, 3. Д, 4. Н, 5. Д

Exercise 4: 1. таваллуд шудааст, 2. бемории, 3. шинос мешавад/шуд, 4. оила, 5. интихоб мешавад/шуд

\section{CHAPTER 6: TAJIK CIVIL WAR}

Exercise 1: 1. b, 2. c, 3. a, 4. b, 5. c

Exercise 2:
1. халк
5. пешрафт
2. Чанг
4. кӯмак
3. Мушкили
1. мардум
4. Дастгирй
3. монеъа
5. Тараққиёт
2. мухориба

Exercise 3: 1. Н, 2. Д, 3. Н, 4. Н, 5. Д

Exercise: 1. Меафзуд, 2. камбуди, 3. Худро, 4. сабабхои, 5. Иштирокчиёни 


\section{CHAPTER 7: MILITARY COLLEGE}

Exercise 1: 1. c, 2. b, 3. b, 4. a, 5. b

Exercise 2:
1. Мудофиа
5. навозандагон
2. Савганд
3. мухориба
3. Харб
4. қасам
4. Савганд
1. дифо
5. Мусиқачиён
2. қасам

Exercise 3: 1. Д, 2. Н, 3. Д, 4. Д, 5. Н

Exercise 4: 1. оғозёбии, 2. забонхои хоричй, 3. метавонанд, 4. ба рох мемонад, 5. Мавчуданд

\section{CHAPTER 8: RELIGIOUS EDUCATION IN TODAY'S TAJIKISTAN}

Exercise 1: 1. a, 2. b, 3. b, 4. c, 5. b.

Exercise 2:
1. Тадқиқот
1. танхо
2. Мулло
3. ёд гирафтан
3. Фаро гирафтан
4. кумак
4. дастгирй
1. пажӯхиш
5. Фақат
2. руххонй

Exercise 3: 1. Н, 2. Д, 3. Н, 4. Н, 5. Д

Exercise 4: 1. омўзонида мешаванд, 2. назорат, 3. мушохида мешавад, 4. дода шуда аст, 5. таълимоти динй

CHAPTER 9: ENTREPRENEURSHIP: THE DRIVING FORCE OF MARKET ECONOMY

Exercise 1: 1. c, 2. b, 3. a, 4. b, 5. a

Exercise 2:
1. самт
4. вазифадор намудан
2. паём
1. чихат
3. таъмин намудан
5. рози кардан
4. супориш додан
2. баёния
5. қонеъ кардан
3. фарохам овардан

Exercise 3: 1. H, 2. H, 3. Д, 4. H, 5. H

Exercise 4: 1. суханронияш, 2. қабул гардида, 3. фурӯши, 4. точирони кишвар, 5. Давлат 


\section{CHAPTER 10: BLOOD PRESSURE AND HEALTH}

Exercise 1: 1. c, 2. b, 3. b, 4. a, 5.c

Exercise 2:

1. маслихат
2. тағйирёбанда
3. дил
4. таркиб
5. майна

4. coxT

3. қалб

1. машварат

5. мағз

2. ивазшаванда

Exercise 3: 1. Д, 2. Н, 3. Д, 4. H, 5. H

Exercise 4: 1. беморон, 2. ба вучуд меоранд, 3. рӯй медихад, 4. таваччӯх, 5. худдори намоянд

\section{CHAPTER 11: CAN AN OLD MAID BE LUCKY?}

Exercise 1: 1. b, 2. c, 3. b, 4. a, 5. c

Exercise 2:
1. чустучӯ
2. харос
2. вохима
1. кофтуков
3. чихат
4. некбахт
4. хушбахт
3. тараф
5. домод
5. шах

Exercise 3: 1. Д, 2. Н, 3. Д, 4. Н, 5. Д

Exercise 4: 1. боқй мемонад, 2. хостгори, 3. хубу бади, 4. ба дунё овардани, 5. чудо

\section{CHAPTER 12: NAVRUZ FESTIVAL}

Exercise 1: 1. c, 2. a, 3. b, 4. a, 5. a

Exercise 2:
1. Хилоф
2. ба хотири
2. Бахри
3. барои
3. Бахри
5. чахон
4. Зиндагй
1. зид
5. Олам
4. хаёт

Exercise 3: 1. Д, 2. Н, 3. Н, 4. Д, 5. Д

Exercise 4: 1. давом доданд, 2. истиқлолият, 3. тайёрй, 4. сохиб гаштааст, 5. ширкат 
TAJIK-ENGLISH GLOSSARY 
абу (n.) - father of

аз кор мондан - to stop working

аз рууи (prep.) - according to, on account of

аз уухдаи (коре) баромадан - to fulfill the task of, to be able (to do), to succeed (in a work)

азиз (adj.) - dear

аланга - flame

аллакай (adv.) - already

амалиёт (n.) - activities , operation

амид-ул-мулк (n.) - chief of the department of official documents [lit. амид - chief, great man; мулк country]

андоз (n.) - tax

андоза (n.) - size, measurement, degree

анъана (n.) - tradition

apaфa (n.) - eve, period before an event; ninth day of the arabic month zul hijja

арбоб (n) - prominent person, notable

артерия (n.) - artery

apȳc (n.) - bride

асабй шудан (v.) - to get nervous

acap (n.) |acapxo, ocop $\mid$ - work of art, monument, composition (of writers)

acно (n.) - time, period of time

acopat (n.) - captivity

aсосгузор (n.) - founder

aтроф (n.) - surroundings, sides атрофиёну наздикон - relatives and neighbors

атфол (n) - children

афзалиятнок (adj.) - preeminent

афзоиши ахолй - population growth

ахолй (n.) - population

ачиб (adj.) - wonderful

ашёи хом - raw materials

аълочии маориф (n.) - an awardee of honor in the field of education in tajikistan

ба коми марг кашидан (v.) - to die, to expire

ба шавхар баромадан (v.) - to marry

ба шарофати - thanks to, by virtue of

баланд (adj.) - high

балки (conj) - but, however

барвақт (adj./adv.) - early

барзгар (n.) |pl. барзгарон $\mid$ - farmer

барзиёд (adj.) - excess, surplus

баровардан (v.) - to take out

бартарй (n.) - superiority

баст (n.) - shift; bundle

бахт (n.) - fate, luck

бахаячонойй (n.) - stress

баxp (n.) - sea

бахри - for, for the sake of, in the interest of 
баъзан (adv.) - sometimes, occasionally

бe (prep.) - without

бевосита (adj.) - direct

бегона (adj.) |бегонагон $\mid$ - foreign, alien

бекор (n.) - unemployed

бемаънигй (n) - nonsense

бемор (adj.) - a sick person

беморй (n.) - disease

бехабар (adj.) - unaware

бинои таълимй (n.) - building for studies

бозсозй (v.) - revival, restoration

боқи мондан (v.) - to remain, to be left

боқимонда (adj.)- the rest of

болиштак (n.) - cushion, pillow

ботантана (adj., adv.) - solemn, solemnly

буддои хуфта - sleeping/reclining buddha

вабо (n.) - cholera

вайрон кардан (v.) - to destroy, to break, to ruin

вақф (n.) - endowment

варамида (adj.) - swollen

васоити таълими (n)- teaching /learning materials

вобаста будан (v.) - to depend on, to be connected with

вогузор шудан (v.) - to pass, to transmit водй (n.) - valley

водор намудан (v.) - to compel, to force водор сохтан (v.) - to oblige, to force

воқеа (n.) - event

воридот (n.) - import

восита (n.) |pl. васоит - instrument, facility; intermediary

вохима (n.) - alarm, fear, panic

воя (n.) - adulthood

ғадуд (n.) - gland

ғайрирасмӣ (adj) - informal

ғaфc (adj.) - thick

гипертония (n.) - hypertension

ғосиб (adj.) - aggressor

гражданй (adj.) - civil (a Russian loanword for шахрвандй)

гузар (n.) - quarter, ward, neighborhood гузари чармгарон - tanners' quarter гузашти айём - with the passage of days

ғуломдорй (n.) - slavery, system of slave owning

ғуломфурушшй - selling of slaves, slave trade

гуманитарй (adj.) - humanitarian [фанхои гуманитарй 'humanities'] гумон (n.) - thought, opinion; suspicion гумон меравад, ки - it is thought that гурда (n.) - kidney 
дабистон (n) - school

давлат (n.) - state

давом - continuation, endurance,

persistence

дақиқ (adj.) - exact

дар ихтиёри (касе) - at (someone's)

disposal

дар (n.) - door

дар арафаи - on the eve of

дар замони (n.) - in the period of

дар миқёси - on the scale of

даргох (n.) - (royal) court

дармонгохи тиббй (n.) - hospital

дархол (adv.) - presently, immediately, at once

дастгирй (n.) - help, assistance

дастгох (n.) - apparatus

дахлдор (adj.) - concerning, relevant

дахолат кардан (v.) - to intervene

девон (n.) - government department, chancery

демократикунони - democratization

диққат - attention

дил (n.) - heart

дин (n)-religion

доду гирифт (also written as

додугирифт) (n.) - trade, trading

relations, barter

домод (n.) - groom донишкадаи харбй (n.) - military

college

доно (n.) - smart

дорой (n) - richness, property

дорулмуаллимини (n.) - teacher

training institute

дуруд (n.) - greeting

дурушт (adj.) - rough, coarse

духтур (n.) - doctor

дучор шудан (v.) - to come across, to be met with

душвор (n.) - difficulty, problem

душворӣ (n.) - difficulty

забт кардан (n.) - conquer

забти осиёи миёна (n.) - occupy of central asia

зебопарастй (adj.) - love of beauty, aestheticism

зиёд (adj.) - many

зикр намудан (v.) - to mention

зиндагй (n.) - life

зудудан (v.) $\mid$ зудо(й) $\mid$ - to file away, to wipe, to clean, to remove

ибни - son of

ид кардан (v.) - to celebrate

идома додан (v.) - to continue

идора (n.) - office, institution

идора кардан (v.) - to manage

издивоч (n.) - marriage 
иқдомот(n.) - effort

иқтисодй (adj.) - economic

иқтисодй (adj.) - economic

илм (n.) - science

илохиётшиносй (n)-theology, divinity

инак - now; behold!, lo!

интернат (n.) - boarding school

интихоб намуданд (v.) - to make a

choice

истехком - fortification, defensive work

истиқлолият (n.) - independence

истило (n.) - conquest, ascendency,

domination

иттифоқи нависандагон (n.) - union of writers

ифтихорй - honorary

ихтиёр (n.) - will,

ихтисос (n.) - specialty

ичтимой (adj.) - public, social

ишғол кардан (v.) - to осcupy

кабуд (adj.) - blue; green (as in чойи кабуд 'green tea')

кайхо (adv.) - long ago, since long

кайхо боз - very long ago, already long ago

калонсол (adj) - elderly

камбудй (n.) - shortcoming, flaw

кандакорй (n.) - engraving, carving китобхона (n.) - library

китобхонаи электронй - library with computers

китобхонаи электронй (n.) - electronic library

кишоварз (n.) |pl. кишоварзон $\mid$ - farmer

корхонахои саноатй - industrial

enterprises, factories

корхои эчодй - creative works

крепостной (n.)- serf

куддакон (n.) - children

кӯй (n.) - street, quarter

курсант (n.) - student

кӯтохмуддат (adj.) - short-term

қалб (adj.) - counterfeit, fraud

қарор додан (v.) - to decide, to make up one's mind

қат (n.) - curve, crease, fold

қисм (n.) - part

қозй (n.) - judge

қолаб/қолиб (n.) - mold, cast

қонеъ кардан (v.) - to satisfy

қофила (n.) - caravan

қофиласолор (n.) - leader (literal:

leader of a caravan)

қуввахои мусаллах - armed forces

қуввахои мусаллахи чумхурии

точикистон (n.) - armed forces

қӯшун (n.) - army, troops 


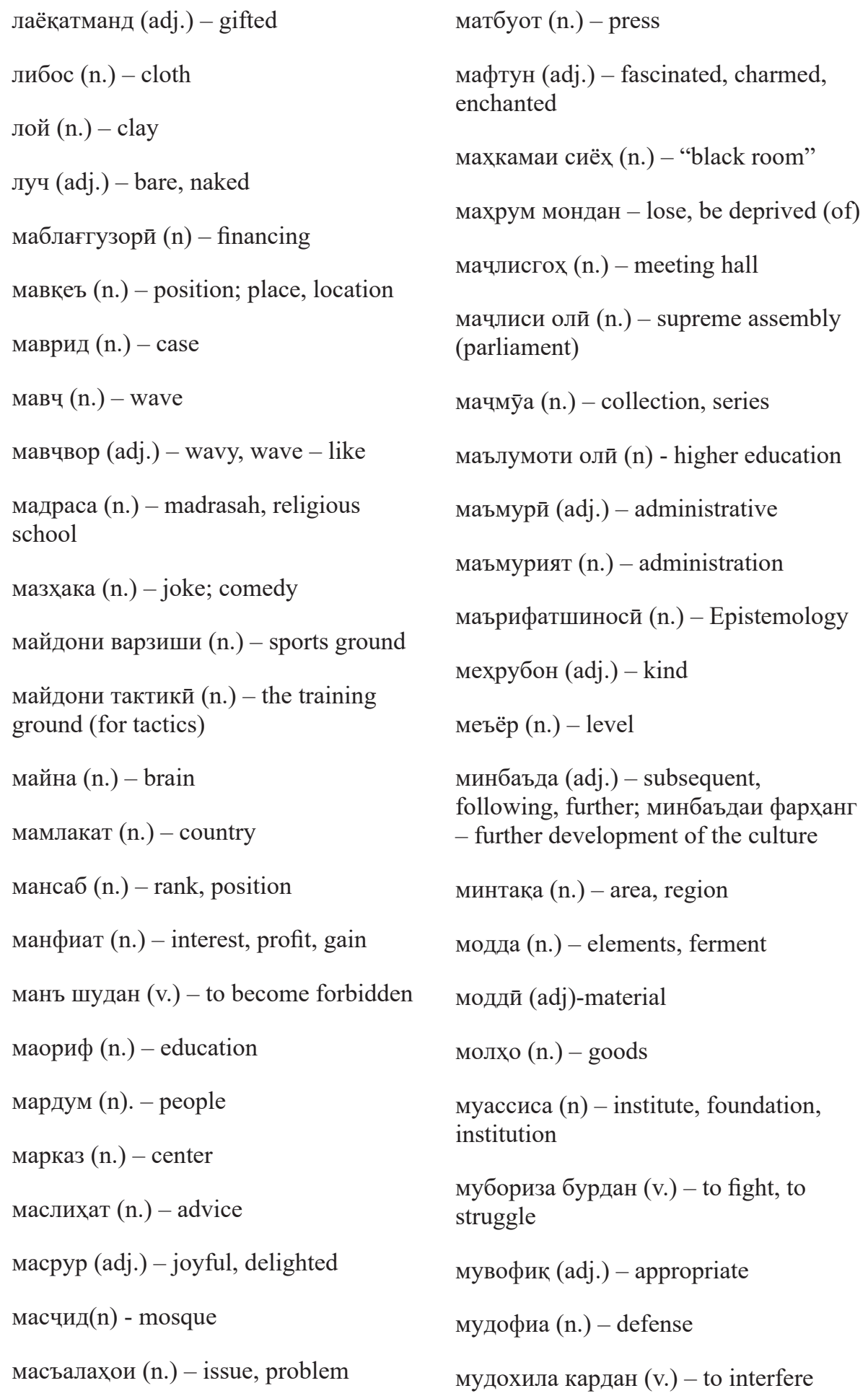


мӯйсар (n.) - hair (of head)

муқаррарй (adj.) - usual, normal

муққадас (adj.) - holy, sacred

муулиён (n.) - name of a river in bokhara

мулк (n.) - property; country, state

мулло (n) - cleric

муноқиша (n.) - conflict, discord

мунтазам (adj.) - regular, systematic, in order

муросилот (pl. of муросила) correspondence

мурури замон - with the passage of time

мусбй (adj.) - positive

мусиқачиён (n.) - musicians

мусобиқахои варзишӣ (adj.) - sports competitions

мусоидат кардан (v.) - to promote, taking initiative

мусоидат кардан (v.) - to help, to assist

муставфй (n.) - treasurer

мустақил (adj.) - independent

мустамлика (n.) - colony, settlement

мутаваччех шудан (v.) - to рау

attention

мутаносиб (adj.) - appropriate

мутантан (adj.) - splendid, luxurious, extravagant

мухити зист (n.) - environment мухтасиб (n.) - police officer, chief of police

мӯхточй кашиданд - to be in need of smth

мушкилй (adj) - difficulty

мушкили (n.) - difficulty, challenge

мушриф (n.) - inspector

навзод (adj.) - newborn

навозиш (n.) - pampering, coddling, caress, kindness

наврӯз (n.) - nowruz holiday

назокат (adj.) - elegance, delicateness, courtesy, refinement

назорат (n.) - supervision, control

намоиш (n.) - show, performance

намуд (n.) - appearance, view

нафаси осуда кашидан - to relax, to be relieved

нашр (n) - publication

начандон - not enough

нек (adj.) - good, glorious

нестй (n.) - non-existence

ниёгон (n.) - ancestors

низом (n) - system, structure

нирвана (n.) - nirvana

номарғуб (adj.) - shoddy, of poor quality

номгӯй (n.) - list, index, directory норозигй - dissatisfaction, disagreement 
нотавонбин (adj.) |нотавонбинон|envious, hateful

обу хаво (n.) - weather

огохй (n.) - information, notice, notification

одамушшуаро - adam of poets

олам (n.) - world, universal

оламгир (adj.) - universal, spread throughout the world

омил (n)- reason

oмȳ (n.) - the river oxus

ориёйй, ориёнажод (n.) - aryan

осорхона (n.) - museum

ошхона (n.) - dining-room

оянда (n.) - future

паём (n.) - message, speech

пардохт (n.) - payment

парки автомобилй (n.) - car park

парниён (n.) - silk

паст (adj.) - low

пахлу (n.) - side

песа (n., russian loanword) - play

пешавар (n.) - craftsman

пештара (adj.) - former, previous

пирдухтар (n.) - old unmarried girl, spinster

подполковник (n.) - lieutenant colonel

пойафзол/поафзол (n.) - footwear почта (n.) - mail, post office

пурзӯр кардан (v.) - to strengthen

пурра (adj.) - complete

пурра (adj., adv.) - whole, full; wholly

пурсучӯй (n.) - search

пурчило (adj.) - shining, glittering, bright

равон (n.) - spirit, psyche, mind, intellect

раг (n.) - vein, artery

рагхои хунгард (n.) - blood vessels

рафту... - and what if

рег (n.) - sand, gravel,

регистон - public square near citadel in samarqand and bukhara

риоя кардан (v.) - to respect, to observe, to keep, to follow

розй шудан (v.) - agree

розигй додан (v.) - agree

рост истодан (v.) - to stand straight

рӯзгор (n.) - life; time, period

рӯхониён (n) - clergymen

рӯшди иқтисодиву ичтимой economic and social development

сабаб (n.) - reason

сабук (adj.) - light

савганд (n.) - oath

сакта (n.) - stroke 
сактаи қалб (russian: инфаркт) (n.) heart attack

сактаи майна (russian: инсулт) - stroke

салтанат (v.) - reign

салтанати сомониён (n.) - samanid sultanate

самаранок (adj.) - profitable, efficacious, productive

самт (n.) - side

санчиш (n.) - test, examination

санъат (n.) - art

сарбоз (n.) - soldier

сарв (n.) - cypress-tree

сарвар (n.) - leader

сарватхои зеризаминй - mineral resources

сардор (n.) - leader

сармоягузорй (n.) - investment

сармоядорй (n.) - capitalism

сарфи назар кардан - to dispense with, to relinquish, to forgo

сахт нигох доштан (v.) - to keep

caxex (adj.) - true

$\operatorname{caxm}(\mathrm{v}$.$) - share$

сигор (n.) - cigarette

сиёсат (n.) - policy, politics

сиёсй (adj.) - political

сиёх (adj.) - black силсила (n.) - series

синну сол (n.) - age

синфхои компютерй (n.) - computer classrooms

созиш (n.) - adaptation, agreement, reconciliation

соли сипаригашта - last year

солим (adj.) - healthy

солор (n.) - leader

coхтор (n.) - structure; сохтори

давлатй - state structure

coxa (n.) - field, area, domain

сохибкор (n.) $\mid$ pl. сохибкорон $\mid-$ businessman, proprietor, entrepreneur

сохибкорй (n.) - entrepreneurship

сохибқирон (adj.) - fortunate, lucky, invincible hero (a title usually given to mighty sultans and kings)

сохиб-ул-барид (n.) - chief of the postal department, postmaster

сохиб-уш-шурот (n.) - captain of the guard [шурта (pl. шурот) - police)]

сохибэътибор (adj.) - respected, honorable

судманд (adj.) - useful

сулх бастан - to sign a peace treaty

супориш додан/кардан (v.) - to give a task, to assign

суфа (n.) - platform

сӯъистеъмол кардан (v.) - to abuse

табобат (n.) - treatment 
таваллуд кардан (v.) - to give a birth

тағйирёбанда (adj.) - changing,

changeable, variable

тадбир (n.) - measure, decision

тадқиқот (n) - research

тадрис (n) - teaching

такмил додан (v.) - to improve

такроран (adv.) - repeatedly

тақсимот (n.) - division

танг (adj.) - narrow

тараққиёт (n.) - progress, development

тарбия (n.) - upbringing, education, training

таркиб (n.) - composition, structure, synthesis

тарозу (n.) - scale

тасаввур кардан (v.) - to imagine

тасма (n.) - strap, belt

тахаллус (n.) - a pen name, a nom de plume

тачлил намудан (v.) - to glorify, to honor

тачриба (n) - practice, experience

тачхизот (n.) - equipment

таъин шудан (v.) - to be appointed

таълим додан (v.) - to train, to teach

таъмин намудан (v.) - to provide

таъминот (n.) - supply таърих (adj.) - history

таъсис ёфтан (v.) - to be created

театри мусиқию мазхака - theater for musical comedy

тибқи омор (n.) - according to statistics

тифл (n.) - child

тозакорй (adj.) - cleanliness, purity, tidiness

тоқча (n.) - niche

толибилм (n.) - pupil, student

толор (n.) - hall

толори лексионй - lecture hall

торафт (adv.) - steadily, continuously

тӯй (n.) - festival, wedding

туллонй (adj.) - long

тӯфон (n.) - storm

уқёнус (n.) - ocean

умумихалқй (adj.) - general, public

унвон (n.) - title

устувор (adj./adv.) - stable, firm, steady, staunch

устура (n.) $\mid$ pl. асотир $\mid$ - myth, legend

усул (n.) - method

фазо (n). - space, atmosphere

фақат (adv) - only

фарз кардан (v.) - suppose

фарзанд (n.) - child

фармондех (n.) - commander 
фаро гирафтан (v) - to learn, to embrace

фархунда (n.) - happy, prosperous

фаъолият бурдан (v.) - to work

фаъолият (n). - activity

фаъолона (adv.) - actively

фирор (n.) - run away, escape

фишанг (n.) - lever; cartridge

фишорбаландй (adj.) - high blood pressure

фозил (adj.) - erudite

фоида (n.) - profit

фоиз (n.) - percent

форам (adj.) - pleasant, pleasing, genial

фосила (n.) - interval

фочиавй (adj.) - tragic

фронт - front

хавфнок (adj.) - dangerous

хазина (n.) - treasury

халқ (n.) - people

харидор (n.) - literal meaning buyer, but it simply means suitor in this context.

хатар (adj.) - danger

хатбари - delivering mail

хатмкунанда (n.) - a graduator

хешовандон (n.) - relatives

хизматрасони (n.) - service

хилоф (adj.) - contrary, opposite хилофат (n.) - caliphate

хинг (n.) - a gray horse

хобгох (n) - dormitory

хонигарй (n.) - khanate

хостан (v.) - to want

хостгор (n.) - suitor

хотир (n.) - memory

худдорй намудан (v.) - to desist, to refrain

хун (n.) - blood

хушбахт (adj.) - happy, lucky

хушбахтона (adj., adv.) - fortunately

хаёти оилавй (n.) - family life

хайат (n.) - body, staff, board

хайкал (n.) - statue

хайкалтарошй (n.) - art of sculpture, sculpting

хайкалхои буддой - statues of buddha

халлу фасл (n.) - settlement, disposition

хаммом (n.) - bathroom

хамсоя (n.) - neighbor

харакат кардан (v.) - to aspire

харб (n.) - war, battle [adj. харбй]

харбй-гражданй - military-civil

хаячон (n.) - excitement, agitation

хидоят намудан (v.) - to guide, to instruct

хизби демократй - democratic party 
хизби нахзати ислом - islamic revival party

хизбхои нави сиёсй - new political parties

холат (n.) - condition

хорич карда шавад(n) - expel, remove хочиб (n.) - chamberlain

худуд (n.) - boundary, limit, border

хукм рондан (v.) - to rule

хукумати шурравй - soviet government

хукумати эътилофй - coalition

government

хунарманд (n.) - artist

хучра(n) - room

хучуми қатъй - serious attack

чайхун (n.) - the river Oxus (or river Bactrus)

чакана (n.) - retail

чалб (n.) - attract

чамъият (n.) - society

чамъиятй (adj.) - social

чамъомад (n.) - congregation

чанг (n.) - war

чармгар (n.) - tanner, a person whose work is tanning hides

чахонбинй (n.) - world view, outlook

чашн гирифтан (v.) - to celebrate

чи навъе ки (adv.) - as чиддй (adj.) - serious

чихат (n.) - side

човидон (adj.) - everlasting, perpetual

чойи тирпаронй (n.) - shooting range

чонбезор (adj.) - dejected, disappointed with life

чорй намудан (v.) - to implement

чорошёна (adj.) - four-storied building чосусй (n.) - espionage

чȳб (n.) - wood

чустучӯ (n.) - search

шайдо (adj.) - fascinated, charmed, infatuated

шароит (n.) - conditions, environment

шароити мусоид - favorable conditions

шахсӣ (adj.) - personal

шахомат (n.) - spirit, courage

шахр (n.) - city

шахраки донишчӯён - it refers to the Tajikistan national university campus and the surrounding area

шахрвандй (adj. ) - civil

шахрвандон (n) - citizen

шиддат (n.) - power, force, intensity шинам - well-fitting [либаси шинам 'well- fitting dress]

шиор (n.) - motto, slogan

ширин (adj.) - sweet 
шоир (n.) - poet

шукӯх (n.) - grandeur, splendor

шӯриш (v.) - revolt

шӯъла (n.) - light, flame эътиқодманд (adj) - faithful

эътимодбахш (adj.) - confidencegiving, assuring

як чанд маротиба - many times 
Tajik Persian: Readings in History, Culture and Society seeks to help students develop reading proficiency in Tajik at advanced level through authentic texts written for native speakers and provides them glimpses into the history, culture and society of Tajikistan without losing its focus on cultural aspects of the country-an aspect that constitutes a core component in the second language acquisition. The book can be adopted by instructors as a supplementary or the main textbook for advanced-level courses.

Razi Ahmad, PhD, is a lecturer at the University of Kansas, Lawrence, where he currently teaches Persian language and lectures on Middle Eastern literatures and cultures.

(C) 2016 Razi Ahmad

ISBN: 978-1-936153-10-7

The University of Kansas Libraries

Lawrence, KS 66045 